\title{
THE EVOLUTION \\ OF THE NOUN CLASS SYSTEM OF NGWI \\ (WEST-COASTAL BANTU, B861, DRC)
}

\author{
Sara Pacchiarotti \\ Ghent University \\ sara.pacchiarotti@ugent.be \\ Koen Bostoen \\ Ghent University \\ koen.bostoen@ugent.be
}

\begin{abstract}
In this paper we offer a first systematic account of the noun class system of Ngwi, a West-Coastal Bantu language spoken in the Democratic Republic of the Congo. First, we describe the synchronic system of noun class prefixes and the agreement patterns they trigger on constituents of the noun phrase and the verb. Second, we provide a diachronic analysis of the innovations the synchronic Ngwi noun class system underwent with respect to the noun class system reconstructed for the most recent common ancestor of all Narrow Bantu languages. Finally, we compare the morphological innovations found in the Ngwi noun class system with those identified in the noun class systems of other West-Coastal Bantu varieties and assess whether some of these could be diagnostic for internal classification within this western Bantu branch.
\end{abstract}

Key words: West-Coastal Bantu, internal classification, noun class system, shared morphological innovations, sound change, paradigm levelling 


\section{Introduction}

This paper is the first synchronic and diachronic account of the noun class system of Ngwi [nlo] (a.k.a. Engwií, Ngwí, Ngul, Nguli, Ngoli, Kingoli), a West-Coastal Bantu (WCB) language spoken south of the Lower Kasai River $(-4.15,19.08)$ in the Kwilu Province of the Democratic Republic of the Congo. In the updated version of Guthrie's (1971) referential classification of the Bantu languages, Ngwi is assigned the alphanumeric code B861 (Maho 2009). While brief descriptions of the Ngwi noun class system exist as part of theses by Congolese students (see, e.g., Nsumuki 1993; Kumpel Wossey 2001; Ayakum 2008; Empenge Itobola 2008; Mulumba 2008), these often do not provide sufficient evidence for the existence of a given noun class (pairing) and their corresponding agreement patterns. ${ }^{1}$ As a result, their analyses are often conflicting for presumably the same variety. The account we offer in this paper is of the eastern variety of Ngwi (Boone 1973: 243-245; MaaluBungi et al. 2011: 18) as spoken in Mangai (-4.02, 19.53), a small town located on the left bank of the Kasai River. Based on the only description of western Ngwi available to us (Kumpel Wossey 2001), lexical, phonological and morphological differences with the eastern variety appear to be significant. The exact number of Ngwi speakers in the DRC today is unknown, but it is definitely not higher than 100.000 and the language is threatened by lingua francas such as Kongo Ya Leta and Lingala. ${ }^{2}$ Children born from parents speaking different WCB minority languages such as Ngwi B861 and Ding B86 are taught mainly Kongo Ya Leta and only a few words in the languages of their parents. This is true also of children born in urban centers from parents speaking the

${ }^{1}$ We know that there are other descriptive materials on Ngwi in the DRC and that parts of the Bible are being translated in this language, but we were unfortunately unable to access these additional materials.

${ }^{2}$ According to Gene \& Djedje (1986), the so-called groupement Bangoli of Oveke, the administrative territory uniting the Ngwi people, counted 8.401 inhabitants in the 1980s. However, not all people who identify ethnically as Ngwi still speak the Ngwi language. 
same language. Data for this paper were collected in Idiofa $(-4.96,19.59)$ during a one-month fieldwork mission (August-September 2019) carried out as part of the BantuFirst project (https://www.bantufirst.ugent.be/). In Idiofa, we worked with two native Ngwi speakers originally from Mangai: Mr. Frédéric Mbeam-Ojuu Empenge Itobola (our main consultant) and Mr. Marako Wosama Ejem. Frédéric (a.k.a. Freddy) was born in 1971 and teaches French in secondary school in Idiofa where he moved in 2011. Besides Ngwi, he speaks Kongo Ya Leta, Lingala, and French. Mr. Marako was born in 1949, speaks Kongo Ya Leta, Lingala and French, and has been living in Idiofa since 1980.

According to the latest and most comprehensive lexicon-based phylogeny of WCB (Pacchiarotti et al. 2019), Ngwi B861 is among the first paraphyletic offshoots of the WCB ancestral node together with Ding B86, Lwel B862, and Nzadi B865. ${ }^{3}$ All of these varieties are spoken in the putative WCB homeland area (Pacchiarotti et al. 2019). While the noun class system of Nzadi is extremely reduced (Crane et al. 2011: 60-74), Ding (Ebalantshim Masuwan 1980: 88 and ff.) and Lwel (Khang Levy 1979: 24 and ff.) still preserve many noun classes and noun class pairings inherited from Proto-Bantu (PB). We show that the noun class system of Ngwi underwent simplification to some extent due to loss of inherited PB classes and mergers of agreement patterns but was also subject to several innovations. As such, it stands halfway between the heavily eroded system of Nzadi and the more conservative systems of Lwel and Ding.

Besides offering a first historically informed account of the Ngwi noun class system, we compare its main morphological innovations with those identified in works on the noun class systems of other WCB varieties (Bollaert 2019; Hyman et al. 2019; Bollaert et al. 2021) to establish whether any of these could be used for the internal classification of this Bantu branch.

${ }^{3}$ The term "paraphyletic" means that Ngwi, Ding, Lwel and Nzadi do not share a more recent common ancestor which is different from the ancestor of the entire WCB branch. 
Noun class systems are one of the main diagnostics to claim Niger-Congo affiliation for any given African language (Hyman 2014). Accounts of noun class systems are usually part of any rudimentary description of a Bantu language, but some of these limit themselves to the enumeration of noun class prefixes without considering the agreement patterns they trigger on other constituents of the noun phrase (NP) and on the verb. As such, they offer a glance at the system but not a full picture of the mechanisms that regulate it. This is all the more true in the northwestern part of the Bantu-speaking area, where many languages are still undocumented or poorly described. Recently, noun class systems have received attention in the literature on linguistic complexity, one of the hypotheses being that their reduction might correlate with socio-geographic variables such as population size, longitude and latitude, forest environment, and contact with non-Bantuphone communities (di Garbo \& Verkerke 2019).

In line with its objectives, this paper is organized as follows. In $\S 2$, we briefly introduce phonological features of Ngwi which are essential to the description of its synchronic noun class system in $\S 3$. In $\S 4$, we discuss the diachronic developments Ngwi underwent with respect to the system considered to be that of the most recent common ancestor of all Narrow Bantu languages, i.e. PB (Meeussen 1969; Maho 1999). We also discuss whether there are shared morphological innovations uniting Ngwi with genealogically and geographically more distant WCB varieties. Conclusions are in $\S 5$.

Throughout this paper, we use a phonetic-driven transcription of the Ngwi data based on the International Phonetic Alphabet (IPA), with the exception of $\langle y\rangle$, which stands for IPA [j]. In the Africanist tradition, $<\mathrm{j}\rangle$ is often used as a grapheme to represent IPA [dz]. We note high tone as $<$ á $>$, low tone as $<$ à $>$, falling tone as $<\hat{a}>$, and rising tone as $<$ ă $>$. We use $* *$ for ungrammatical/unacceptable examples and * for protoforms. This account is based on a database including 625 nouns at present. The symbol > means 'evolved into', while $<$ means 'diachronically derived from'. 


\section{Phonological features of Ngwi}

In this section, we briefly introduce the consonant and vowel systems of Ngwi and discuss (supra)segmental processes affecting nouns and other elements of the NP which are immediately relevant to understand the data presented in $\S 3$. Evidence for the phonemic status of Ngwi consonants and vowels can be found in Pacchiarotti \& Bostoen (in prep.). The 36 consonant phonemes of Ngwi are shown in Table 1. We consider all consonants listed in Table 1 as single units. /z/ is in parentheses because it is a marginal phoneme (i.e. it occurs only in one word in our database). "Pre-N" stands for pre-nasalized, "lab.v." for labiovelar, and "lab.d." for labiodental. We note that /b/ is realized as $[\beta]$ intervocalically and word-finally, $/ y /$ is realized as $[j]$ in word final position and $/ \mathrm{r} /$ is realized as [ $\mathrm{r}$ ] intervocalically and after a consonant. In word-final position, $/ \mathrm{r} /$ can be realized as [R]. In fast speech, word-final /b/ and / $\mathrm{B} /$ can be realized as zero.

Table 1

Ngwi consonant phonemes

\begin{tabular}{|c|c|c|c|c|c|c|c|c|c|}
\hline & labial & lab.d. & lab.v. & dental & alveolar & postalv. & palatal & velar & uvular \\
\hline plosive & $\mathrm{p} \quad \mathrm{b}$ & & & $\mathrm{t}$ & & & & $\mathrm{k}$ & \\
\hline nasal & $\mathrm{m}$ & & & & $\mathrm{n}$ & & $\mathrm{n}$ & $y$ & \\
\hline fricative & & f $\quad v$ & & & s $\quad(\mathrm{z})$ & $\int 3$ & & & в \\
\hline affricate & $\mathrm{pf}$ & & & & ts $\mathrm{dz}$ & $\mathrm{t} \int \mathrm{d} 3$ & & & \\
\hline $\begin{array}{c}\text { pre-N } \\
\text { plosive }\end{array}$ & $\mathrm{mp} \mathrm{mb}$ & & & nt nd & & & & yk & \\
\hline $\begin{array}{c}\text { pre-N } \\
\text { fricative }\end{array}$ & & $\mathrm{mf} \mathrm{mv}$ & & & & & & & \\
\hline $\begin{array}{l}\text { pre-N } \\
\text { affricate }\end{array}$ & $\mathrm{mpf}$ & & & & nts $\mathrm{ndz}$ & nt $\int \mathrm{nd} 3$ & & & \\
\hline trill & & & & & $\mathrm{r}$ & & & & \\
\hline glide & & & $\mathrm{W}$ & & & & $\mathrm{y}$ & & \\
\hline lateral & & & & & 1 & & & & \\
\hline
\end{tabular}


As can be seen from Table 1, Ngwi distinguishes seven manners of articulation: plosive, nasal, fricative, affricate, flap, approximant and lateral. Pre-nasalized plosives, fricatives and affricates only occur at the beginning of noun roots. They are the outcome of the historical reanalysis of $\mathrm{PB} \mathrm{CL} 9 / 10 * N-/ * N$ - homorganic nasal prefixes as part of the simple noun stem. According to our data, all consonants in Table 1 can appear in word- and/or syllable-initial position, except / $\mathrm{b} /$ and /r/. Only /m/, /n/, /n/, /n/, /r/, / / /, /y/ and /b/ are attested in syllable- and/or word-final position (in words which do not undergo partial or full reduplication of the stem). This left-to-right asymmetry in the occurrence of consonants within the stem is a common phenomenon in the northwestern portion of the Bantu-speaking area (Hyman 2008: 331).

A noteworthy morphophonological process affecting certain consonants is so-called strengthening or fortition after a nasal. Postnasal strengthening is very common in Bantu languages (cf. Odden 2015; Hyman 2019: 138; Maddieson \& Sands 2019: 112). In Ngwi, through this process, glides and laterals become stops and fricatives become affricates, as shown with the singular/plural alternation of nouns belonging to classes $7 \mathrm{e} / 8 \mathrm{~N}$ in (1).

\begin{tabular}{|c|c|c|c|c|}
\hline$/ \mathrm{N}+\mathrm{w} /$ & $\rightarrow$ & $\begin{array}{l}\text { SG } \\
\text { è-wúò }\end{array}$ & $\begin{array}{l}\text { PL } \\
\text { ṁ-búò }\end{array}$ & 'arm' \\
\hline$/ \mathrm{N}+\mathrm{w} /$ & $\rightarrow$ & è-wúù & ̀̀-gúù & 'metal' \\
\hline$/ \mathrm{N}+\mathrm{y} /$ & $\rightarrow$ & $\grave{e}-y \check{\text { ъ }}$ & $\grave{n}-d z u ̌ s$ & 'peanut' \\
\hline$/ \mathrm{N}+1 /$ & $\rightarrow$ & $\grave{e}-l \hat{\varepsilon} B$ & $\grave{n}-d \hat{\varepsilon} B$ & 'weaver bird' \\
\hline$/ \mathrm{N}+\mathrm{s} /$ & $\rightarrow$ & è-síà & $\grave{n}$-tsíà & 'feather' \\
\hline
\end{tabular}

Another morphophonological process affecting consonants is depalatalization triggered by a central vowel. This is shown in (2) with noun roots starting in a non-central vowel and taking the noun class prefix of CL5 $d z^{-}$which is realized as [dz] when the noun root starts with /ə/. 


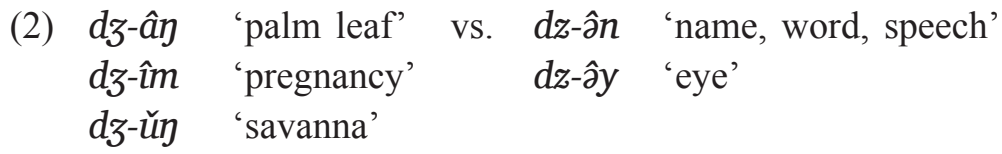

The vowel phonemes of Ngwi are shown in Table 2. These vowel phonemes occur only short. Ngwi does not have contrastive vowel length.

Table 2

Ngwi vowel phonemes

\begin{tabular}{l|c|c|c|} 
& front & central & back \\
\hline close & $\mathrm{i}$ & & $\mathrm{u}$ \\
\cline { 1 - 1 } close-mid & & & $\gamma$ \\
\cline { 1 - 1 } open-mid & $\varepsilon$ & $\partial$ & 0 \\
\cline { 1 - 1 } open & & $\mathrm{a}$ & \\
\hline
\end{tabular}

In the absence of a conditioning environment, the open-mid front and back vowels of Ngwi are realized as [ $[\varepsilon]$ and [0] respectively. However, the $o$ - prefixes of CL1 (<PB *mù-), CL3 (< PB *mù-) and CL11 ( $<\mathrm{PB} * d \dot{\text { - }}$ ) are always realized as [o] and the $e$ - prefixes of CL4 (PB *mì-) and CL7e (PB *kì-) always as [e]. In 7-vowel Bantu languages such as Mongo C61 (de Rop 1958), [e] and [o] usually arise diachronically from the lowering of $\mathrm{PB}{ }^{*} I$ and $* U$ respectively (cf. supra). However, anywhere else in the Ngwi lexicon, PB *I and ${ }^{*} U$ merged with PB $* i$ and $* u$ respectively, yielding /i/ and $/ \mathrm{u} /$. In principle, [e] and [o] in Ngwi can be shown to contrast with other vowels in word initial position, e.g. è-tûn 'CL7-enemy' vs. ì-tûn 'CL8-enemy', ò-fúy 'CL3-tree' vs. è-fúy 'CL4-tree'. Nevertheless, we refrain from giving [e] and [o] phonemic status, because their distribution is morphologically heavily restricted. They can occur only as realizations of noun class prefixes and agreement morphemes of nouns belonging to the corresponding class. For this reason, we consider them as sub-phonemic (Garrett 2014: 239; Honeybone \& Salmons 2014). 
Root-internally, $/ \mathrm{i} /$ and $/ \mathrm{u}$ / trigger vowel heightening in the openmid vowels $/ \varepsilon /$ and $/ \mathrm{J} /$ which are then realized as /e/ and /o/ respectively, as in (3). The /i/ of CL5 and CL8 prefixes does not trigger vowel heightening within the noun stem, e.g., ì-kôm 'CL5-broom'.
(3)

\begin{tabular}{|c|c|c|c|}
\hline tìé/ & $\rightarrow$ & [tìé] & 'ripen'4 \\
\hline$/ m v$ & $\rightarrow$ & [mvúyè] & 'rain' \\
\hline $\mathrm{zu}$ & & [dzùó] & civet cat(s)' \\
\hline is & $\rightarrow$ & [lòtfúù] & 'yesterday' \\
\hline
\end{tabular}

We now turn to suprasegmental features. There are two primary tones in Ngwi, High $(\mathrm{H})$ and Low (L). These level tones can combine into $\mathrm{HL}$ and $\mathrm{LH}$, which are realized as $\mathrm{F}$ (alling) and $\mathrm{R}$ (ising) respectively on CVC stems. The resulting four tones are lexically (and grammatically) contrastive as shown with the pairs and triplets in (4).
(4) èkùó 'sunset' èkúò 'tribes'
ikôm 'broom' ikòm 'flaws'
àvèár 'wives' àvéàr 'people'
$\eta k w \hat{n} n$ 'beans' $\quad \eta k w$ ว̌n 'crocodile(s)'

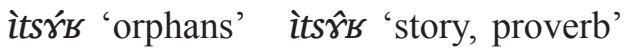
àpfún 'testicles' àpfǔn 'burials'

èkúó 'umbilical cords's

ikǒm 'Myrianthus arboreus (fruit)'

${ }^{4}$ Uninflected non-finite verb roots in Ngwi do not carry a noun class prefix when elicited in isolation. Often, when speakers are asked to translate French infinitives they give first person present tense verb forms. This is remarkable from a comparative Bantu point of view.

5 In Pacchiarotti et al. (under review), we present evidence to treat vowel sequences such as /u.o/ (where <.> indicates a syllable break) in èkùó 'sunset' as a sequence of two heterosyllabic vowels instead of a diphthong, e.g., [wǒ]. 
The main tone process at the NP level in Ngwi is rightward $\mathrm{H}$ tone spreading. Both $\mathrm{H}$, see (5) and (6), and R tones, see (7), can trigger rightward $\mathrm{H}$ tone spreading within the limits of the NP.

\begin{tabular}{|c|c|c|c|}
\hline né/ & & [ykúm éné] & 'this chief' \\
\hline & & [mpèám éné] & 'this antelope (sp \\
\hline /mbwว̌m ìpà/ & & [mbwว̌m ípá] & 'two noses' \\
\hline
\end{tabular}

A $\mathrm{H}$ tone at the end of a word can propagate rightward even if its hosting element is deleted in vowel elision processes preventing sequences of three vowels in a row across morpheme boundaries. Consider (8) and (9), where the apostrophe indicates a deleted vowel.
(8) /èkùó èn $\varepsilon / \rightarrow$ [èkù' énć] 'this sunset'
(9) /èkúò èn $\varepsilon / \rightarrow$ [èkú' ènć] 'these tribes'

In (8), /’́/ in /èkùó/gets deleted but its floating $\mathrm{H}$ tone is realized on the underlyingly L-toned agreement prefix $\grave{e}$ - of the demonstrative. By contrast in (9), there is no $\mathrm{H}$ tone propagation because / $/$ / in /èkúj/ is L-toned. The preceding $\mathrm{H}$ tone on /u/ in /èkúj/ is unable to spread because it is followed by a $\mathrm{L}$ tone vowel that even if deleted leaves a floating $\mathrm{L}$ tone which prevents $\mathrm{H}$ tone spreading.

If the last constituent of a NP has a F (or HL) or R (or LH) tone, a spreading $\mathrm{H}$ tone cannot change this contour tone pattern into $\mathrm{H}$ or $\mathrm{HH}$, as shown in (10) and (11) (see Pacchiarotti \& Bostoen in prep. for additional examples).
(10) /òkว̌r ò vân/ $\rightarrow$ [òkว̌r ó vân]
'toothbrush (lit. creeper of teeth)'
(11) /ndzèám è bùú/ $\rightarrow$ [ndzèám é bùúu
'parent (lit. god of the earth)'

Similarly, a $\mathrm{H}$ tone cannot spread onto the verb phrase (VP) and override the tone melody of a particular conjugation. 
As can be observed in (8) and (9), vowel elision processes prevent sequences of three vowels in a row across word boundaries. The vowel that gets deleted is always the left most. Whenever a sequence of two vowels is created across word boundaries, vowel elision may take place in fast speech, as in (12).

\section{(12) /îkùkù ì tìí/ $\rightarrow$ [ìkùk' ì tî́] \\ 'dung beetle (lit. beetle of the excrements)'}

\section{A synchronic account of the Ngwi noun class system}

\subsection{General considerations}

Following Kadima (1969: 82), the three formal criteria we use to identify a noun class are: (i) the agreement pattern the noun triggers on other constituents of the NP and VP (e.g. agreement prefixes on numerals, adjectives, demonstratives, etc., subject and object indexes); (ii) the shape of the noun class prefix a given noun root takes; and (iii) the singular/plural noun class pairing the noun belongs to. According to Kadima (1969), two noun classes are different if: (a) they differ in the agreement patterns they trigger; or (b), they trigger the same agreement patterns but their noun class prefixes and pairings are both distinct from that of another class. Table 3 presents the noun classes of Ngwi following Kadima's (1969) criteria. $N$ - stands for a homorganic nasal. In the column Conn(ective), the morpheme to the right of the symbol $\sim$ is an alternative but less common realization of the morpheme to the left of $\sim$. For each noun class (CL), we include the noun class prefix and the agreement morphemes triggered on the constituents of the NP (adjectives, numerals, demonstratives, possessives), including the connective (CONN) construction, and on the VP (subject and object indexes). ${ }^{6}$ Note that classes 3-6 have more than one noun

${ }^{6}$ In Bantu and Niger-Congo scholarship more generally, the term "connective" or "associative" refers to a construction where a head noun is modified by another noun usually introduced by a relator called connective, associative or genitive 
class prefix separated by a slash (see, e.g., CL4 $\grave{o}-/ w$-). These are phonologically conditioned allomorphs: the vocalic prefix is used when the noun root starts in a consonant, while the consonantal prefix is used when the noun root starts in a vowel (see Table 4 for examples). The numbering of noun classes follows the one used for PB (Meeussen 1967) and reflects the Niger-Congo tradition whereby odd numbers indicate singular classes and even numbers plural classes.

As can be seen from Table 3, the vast majority of noun classes have one and the same agreement morpheme across the board. The pervasive paradigm leveling undergone by noun class agreement morphemes is reminiscent of what Koni Muluwa \& Bostoen (2019: 422) report for Nsong B85d, another WCB variety. However, because connectives can be zero in classes 1,2 and $7 \varnothing,{ }^{7}$ we still distinguish between different NP agreement paradigms in Table 3 instead of merging them into one single adnominal agreement paradigm as Koni Muluwa \& Bostoen (2019: 422) do for Nsong. Unlike many Bantu languages, Ngwi does not have formally distinct independent pronouns, a.k.a. "substitutives" (cf. Kamba-Muzenga 2003), for each class. As far as we can tell, Ngwi has no locative noun classes.

In Table 3, subject indexes are underlyingly $\mathrm{H}$-toned but whenever they are followed by a H-toned TAMP (Tense Aspect Mood Polarity) morpheme, their tone changes to $\mathrm{L}$ (Pacchiarotti in prep.). On the other hand, object indexes are always L-toned and do not interact with the tone melody of the verb stem, unlike what commonly happens in (Eastern) Bantu languages (Marlo \& Odden 2019: 162). Segmentally, object indexes differ from subject indexes in that the forms for human referents of CL1 (singular) and CL2 (plural), $\grave{o}$ - and $\grave{a}-$ respectively, have generalized to all other classes, regardless of the animacy of the noun. Alternatively, object NPs can be pronominalized as postverbal

(Van de Velde 2013: 217). This construction is used to express a variety of meanings, one of them being possession.

${ }^{7}$ The zero form of the connective for subclass $7 \varnothing$ occurs only with some nouns denoting human referents and belonging to class pairing 7Ø/2 
independent pronouns. In this case, singular and plural third person objects are expressed by ndé and wó respectively, also regardless of their animacy.

Table 3

Ngwi noun classes and agreement patterns

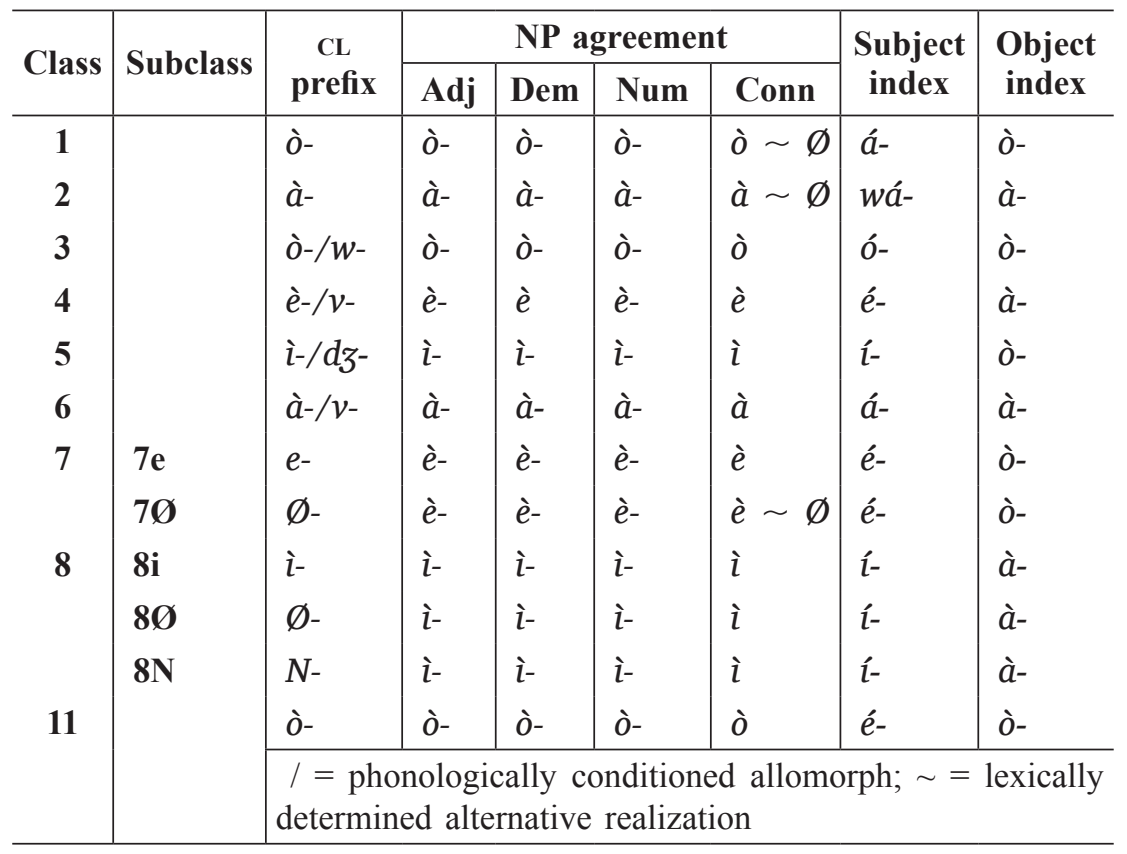

As shown in Table 3, Ngwi has nine noun classes. There are five singular classes $(1,3,5,7,11)$ and four plural classes $(2,4,6,8)$. Class 7 has two subclasses: $7 \mathrm{e}$ and $7 \varnothing$. Class 8 has three subclasses: $8 \mathrm{i}, 8 \varnothing$, and $8 \mathrm{~N}$. These nine noun classes can combine into nine noun class pairings, ${ }^{8}$ as shown in Figure 1. Nouns lacking a singular or

${ }^{8}$ In Bantu studies, the term "gender" is often used after Corbett (1991) to refer to noun class pairings (Van de Velde 2019: 238), but it can also refer to individual noun classes (Maho 1999: 3). For this reason, we use the more transparent term "noun class pairing". 
a plural counterpart occur in classes $3,6,7,7 \mathrm{e}, 7 \varnothing$, and $8 \varnothing$. Borrowings occur in noun class pairings $3 / 4,5 / 6,7 \mathrm{e} / 8 \mathrm{i}, 7 \varnothing / 8 \varnothing$ (where $\varnothing$ stands for a zero noun class prefix), and $11 / 8 \mathrm{~N}$.

SG

PL

$\begin{array}{ll}1 & \text { ò- } \\ 3 & \text { ò- } \\ 5 & \text { ì- } \\ 7 \mathrm{e} & \text { è- } \\ 7 \varnothing & \emptyset- \\ 11 & \text { ò- }\end{array}$

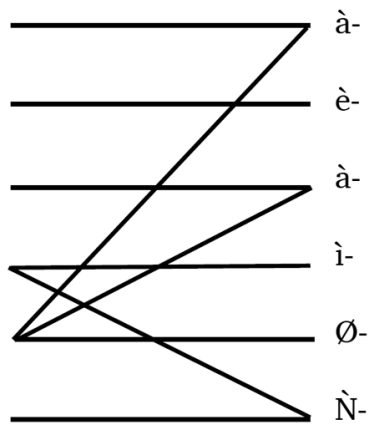

2

4

6

$8 \mathrm{i}$

$8 \emptyset$

Figure 1. Ngwi noun class pairings

Table 4 gives an example of each noun class pairing in Figure 1 along with the amount of nouns in our database which belong to that pairing.

Table 4

\section{Examples and percentages of nouns occurring in each noun class pairing}

\begin{tabular}{|c|c|c|c|c|c|c|}
\hline SG & & PL & & & \# of nouns & $\%$ \\
\hline 1 & 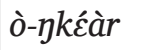 & 2 & 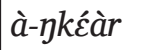 & 'woman' & 30 & 5.2 \\
\hline 3 & $\begin{array}{l}\text { ò-mpûy } \\
w \text {-âr }\end{array}$ & 4 & $\begin{array}{l}\grave{e} \text {-mpûy } \\
v^{y} \text {-âr }\end{array}$ & $\begin{array}{l}\text { 'pangolin' } \\
\text { 'canoe' }\end{array}$ & $\begin{array}{l}108 \\
11\end{array}$ & 20.7 \\
\hline 5 & $\begin{array}{l}\text { ì-kì } \\
d z \text {-ây }\end{array}$ & 6 & $\begin{array}{l}\text { à-kì } \\
v \text {-ây }\end{array}$ & $\begin{array}{l}\text { 'egg' } \\
\text { 'eye’ }\end{array}$ & $\begin{array}{l}138 \\
16\end{array}$ & 26.8 \\
\hline $7 \mathrm{e}$ & $\grave{e}-p f u ̂ y$ & $8 \mathrm{i}$ & ì-pfûy & 'calabash' & 45 & 7.8 \\
\hline $7 \mathrm{e}$ & è-lâm & $8 \mathrm{~N}$ & ǹ-dâm & 'tongue' & 57 & 10 \\
\hline $7 \varnothing$ & $\emptyset-m b w \check{m}$ & $8 \varnothing$ & $\emptyset$-mbwǒm & 'nose' & 142 & 24.8 \\
\hline
\end{tabular}


End of table 4

\begin{tabular}{|c|c|c|c|c|c|c|}
\hline SG & & PL & & & \# of nouns & $\%$ \\
\hline $7 \varnothing$ & $\emptyset$-wèár & 2 & à-vغ̀ár & 'wife' & 16 & 2.8 \\
\hline $7 \varnothing^{9}$ & $\emptyset$-vâm & 6 & à-vâm & 'thing' & 2 & 0.3 \\
\hline \multirow[t]{2}{*}{11} & $\grave{o}$-sว̌b & $8 \mathrm{~N}$ & $\grave{n}$-tsšb & 'intestine' & 9 & 1.6 \\
\hline & & & & Total & 574 & 100 \\
\hline
\end{tabular}

\subsection{Major noun class pairings}

The following subsections describe noun class pairings featuring at least nine nouns.

\subsubsection{Class pairing $1 / 2$}

Nouns in this class pairing take $\grave{o}$ - in the singular and $\grave{a}-$ in the plural. All 1/2 nouns refer to humans or events involving humans (see, e.g., 'burial'). They include professions, a few kinship terms, names of ethnic groups, and agentive nouns as shown in (13).

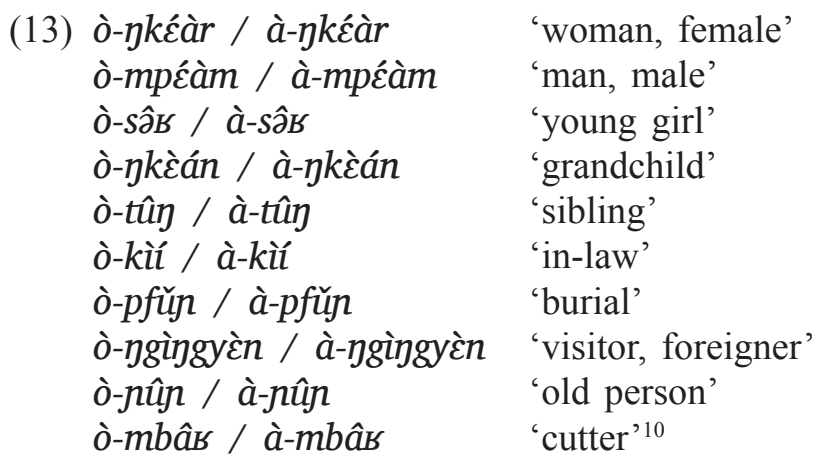

${ }^{9}$ Class pairing 7/6 contains only two nouns (see $\$ 3.2$ ). In the singular, one of the nouns takes $\grave{e}$ - and the other (illustrated in Table 4) takes $\emptyset$-. We arbitrarily chose to represent this class pairing in Figure 1 with subclass $7 \varnothing$ instead of subclass $7 \mathrm{e}$.

${ }^{10}$ The nasal present in agentive nouns such as 'cutter', 'maker', and 'killer' is probably part of the deverbal derivation process which gives rise to these nouns. 


\begin{tabular}{|c|c|}
\hline 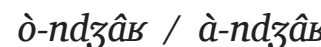 & 'killer' \\
\hline ò-nkìè / à-nkì̀ & 'maker' \\
\hline ò-ntsâr / à-ntsâr & 'traitor' \\
\hline 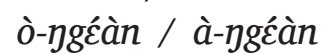 & 'doctor' \\
\hline 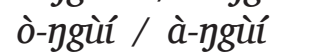 & 'Ngwi person' \\
\hline$\grave{o}-d z i \eta \eta$ & 'Ding person' \\
\hline ò-lwčr / à-lwšr & 'Lwel person' \\
\hline 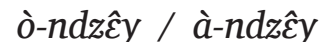 & 'Nzadi person' \\
\hline
\end{tabular}

Evidence for the agreement patterns of the nouns in (13) are in (14)-(21).

(14) òmpéàm òkùikùì òní ófúè lîm èné álí òtûy mé

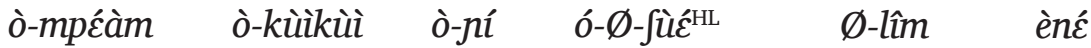

CL1-man 1-short:INT 1-that s1-GEN.PRS-sing CL8Ø-song this

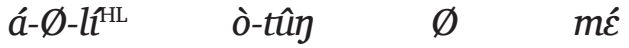

S1-GEN.PRS-be CL1-brother 1.CONN 1sG

'That short man who sings songs is my brother (lit. that short man sings songs this is my brother).' ${ }^{11}$

(15) àykéàr àsâr àtítêy àní wásúi ìlèám

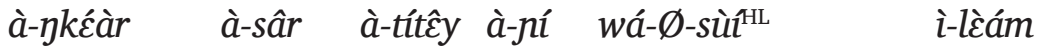

CL2-woman 2-three 2-tall 2-that s2-GEN.PRS-wash.TR CL8-cloth

'Those three tall women wash clothes.'

(16) ńdòòŷ̂n

$\hat{N}-y a ̀-o ̀-y \hat{\varepsilon ̂ n ~} n^{\mathrm{HL}}$

S1SG-PRS.PROG-O.SG-See

'I am seeing her (the woman).'

${ }^{11}$ A superscript $\mathrm{HL}$ or $\mathrm{H}$ on a verb form indicates melodic $\mathrm{HL}$ and melodic $\mathrm{H}$ respectively (Odden \& Bickmore 2014). Most TAMP constructions in Ngwi feature melodic $\mathrm{H}$ or HL with scope exclusively on the verb root/simple stem (see Pacchiarotti in prep.). 
(17) ńdààyên

$\hat{N}-y \grave{a}-a ̀-y \hat{\varepsilon} n^{\mathrm{HL}}$

S1 SG-PRS.PROG-O.PL-See

'I am seeing them (the women).'

(18) òjkéàr ò wì óní

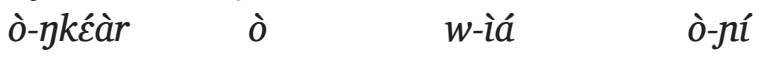

CL1-woman 1.CONN CL3-village 3-that

'the woman of that village'

(19) ànkéàr à wì óní

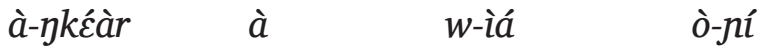

CL2-woman 2.CONN CL3-village 3-that

'the women of that village'

(20) òjkì èbènć

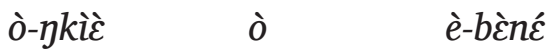

CL1-maker 1.CONN CL7-iron

'blacksmith (lit. maker of the iron)'

(21) ànkì ìbèné

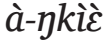
$\grave{a}$
ì-bèné
CL2-maker
2.CONN
CL8-iron
'blacksmiths (lit. makers of the irons)'

Note that the connective morpheme is realized only if the following noun stem starts in a consonant, as in (18) and (19). When the following noun stem starts in a vowel, as in (20) and (21), the connective surfaces as zero. This is true for all nouns and all noun classes. However, CL1 nouns can trigger ò or $\varnothing$ as a connective element (see Table 3) regardless of whether the following noun starts in a vowel or a consonant. This alternation is either free or lexically conditioned. In (14), ò-tûy 'brother' triggers a $\emptyset$ connective on the following pronoun, but the $\grave{o}$ connective, e.g. $\grave{o}$-tûy $\grave{o} m \dot{\varepsilon}$, is also possible according to our main consultant. Other cL1 nouns take only ò (e.g. ò-ygéàn ò $m \varepsilon \dot{\varepsilon}$

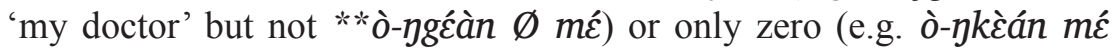

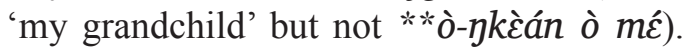


Finally, the object indexes in (16) and (17) could be used anaphorically for any human, animate or inanimate referent regardless of the class to which the noun belongs (see examples in the following sections).

\subsubsection{Class pairing $3 / 4$}

This noun class pairing has two sets of prefixes in phonologically conditioned complementary distribution: $\grave{o}-/ \grave{e}-$ and $w-/ \nu$ - Noun roots starting in a consonant take $\grave{o}$ - in the singular and $\grave{e}-$ in the plural, as in (22). The few noun roots starting in a vowel take $w$ - in the singular and $v$ - in the plural, as in (23). Semantically speaking, CL3/4 includes nouns for body parts, animals (small mammals, reptiles, insects, shellfish), plant species, objects, substances, abstract and collective nouns, human qualities and activities.

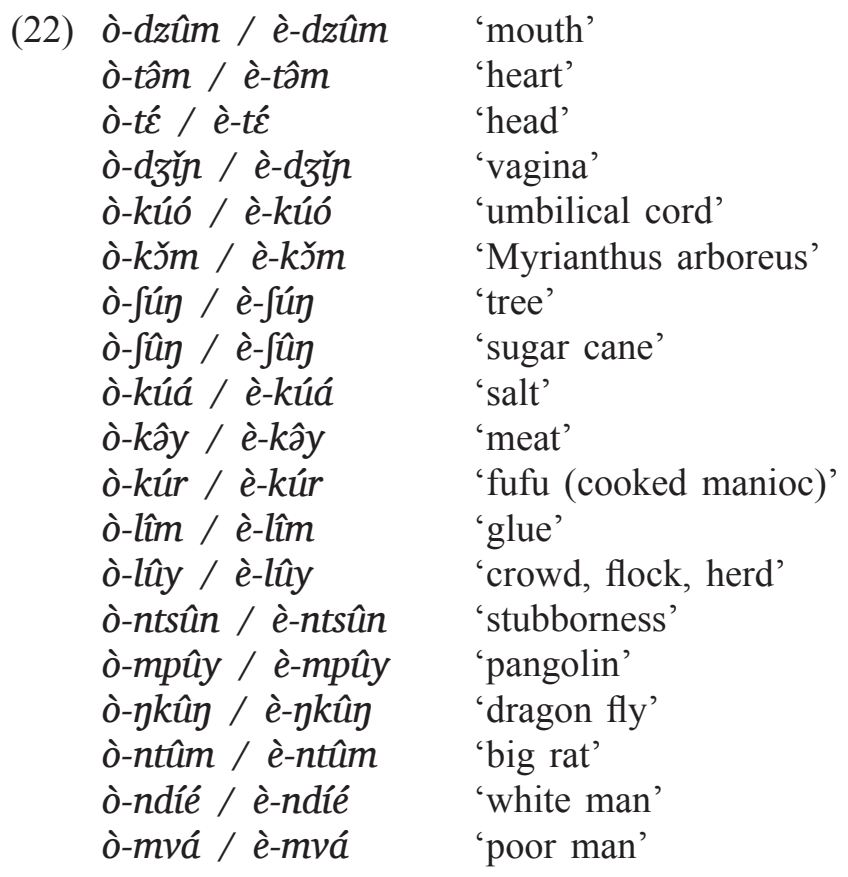




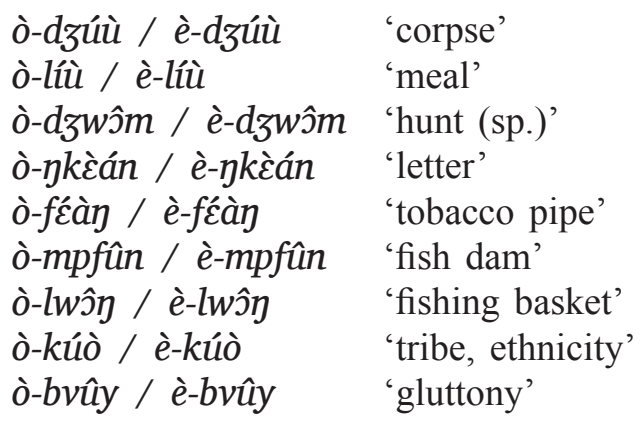

\begin{tabular}{|c|c|}
\hline v-âr / v -âr & 'canoe' \\
\hline$w-\hat{\varepsilon} r / v^{y \hat{\varepsilon} r}$ & 'star' \\
\hline$w$-iá / v-iá & 'village' \\
\hline$w$-ân / $v^{y}-\hat{a} j$ & 'path (created by man)' \\
\hline$w$-ǔm / v-ĭm & 'theft' \\
\hline$w$-ì $/ v$-ì & 'bone' \\
\hline$w$-ăg / v $v^{y}-a_{j}$ & 'intelligence' \\
\hline$w-\hat{\varepsilon} \eta / v^{w}-\hat{\varepsilon} r$ & 'fish (sp.)' \\
\hline -ìn / v-ìn & 'arrow' \\
\hline$-\hat{\imath} n / v-\hat{\imath} n$ & 'handle' \\
\hline
\end{tabular}

The agreement morphemes triggered on the NP and the verb by CL3/4 nouns in (22) and (23) are shown in (24)-(33).

(24) òmpûy òmôs ònên òídzárm

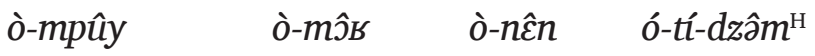
CL3-pangolin 3-one 3-big S3-PRF-disappear 'One big pangolin has disappeared.' 12

(25) èmpûy ènĉn èní èídzá:m
è-mpûy
è-nर̂n è̀-ní
é-tí-dzâm ${ }^{\mathrm{H}}$
CL4-pangolin
4-big 4-that
s4-PRF-disappear
'Those three big pangolins have disappeared.'

${ }^{12}$ The perfect marker $t^{\prime}$ - is often realized as $i^{-}$on the surface. Both realizations are in free variation. We opt here to consider the segmentally heavier allomorph as the underlying form. 
(26) òlí èkùó

\begin{tabular}{lll} 
ò-liù & \multicolumn{1}{c}{} & \multicolumn{1}{c}{ è-kùó } \\
CL3-meal & 3.conN & CL7-sunset \\
'dinner (lit. & meal of the sunset)'
\end{tabular}

(27) èlí è yăn

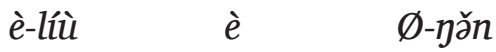

CL4-meal 4.CONN CL7Ø-center

'lunches (lit. meals of the center)'

(28) $w \hat{\varepsilon} r$ ò mbûb
$w$-ह̂े
ò
$\emptyset$-mbûs
CL3-star
3.CONN
CL7Ø-path
'guide (lit. star of the path)'

(29) $v^{y} \hat{\varepsilon} r$ è mbûb
$v^{y}-\hat{\varepsilon} r$
$\grave{e}$
$\emptyset$-mbûs
CL4-star
4.CONN CL8Ø-path
'guides (lit. stars of the paths)'

(30) wâr òtêy òní òivrámá
$w$-âr
$\grave{o}-t \hat{\varepsilon} y$
ò-ní
ó-tí-vrámám ${ }^{\mathrm{H}}$
CL3-canoe 3-long
3-that
s3-PRF-capsize
'That long canoe has capsized.'

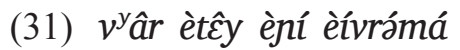

$v^{y}$-âr è-tĉy è-ní é-tí-vrómám

CL4-canoe 4-long 4-that s4-PRF-capsize

'Those long canoes have capsized.'

(32) ńdòòŷn

$\hat{N}-y a ̀-o ̀-y \hat{\varepsilon} n^{\mathrm{HL}}$

s1sG-PRS.PROG-O.SG-See

'I am seeing it (the pangolin / the canoe).'

(33) ńdààyên

$\hat{N}-y \grave{a}-a ̀ a-y \hat{\varepsilon} n^{\mathrm{HL}}$

S1sG-PRS.PROG-O.PL-See

'I am seeing them (the pangolins / the canoes).' 
Besides humans (see (16)-(17)), CL1 ̀̀- and CL2 à- object indexes can also be used to refer anaphorically to animate and inanimate referents, as shown in (32)-(33). See (49)-(50) and (60)-(61) for additional examples.

\subsubsection{Class pairing $5 / 6$}

As it happens with $3 / 4$ nouns, nouns in this class pairing have two phonologically conditioned allomorphic sets of noun class prefixes. They take $\grave{i}$ - in the singular and $\grave{a}$ - in the plural when the noun root starts in a consonant, as in (34), and dz- in the singular and $v$ - in the plural if the root starts in a vowel, as in (35). Semantically, this class pair includes nouns for human and animal body parts, plant species, animals (especially fish, insects, reptiles and a few mammals), human states and qualities, objects, landscape elements, places, fruits and vegetables, quantities, substances and speech acts.

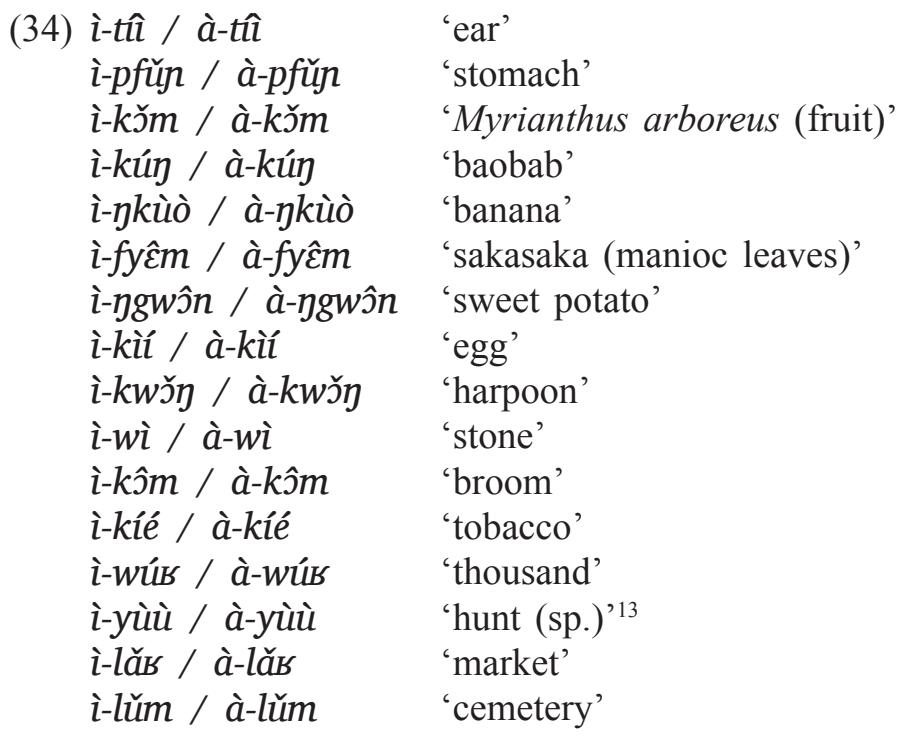

${ }^{13}$ This word designates a type of hunting involving the participation of many people and the use of many traps. 


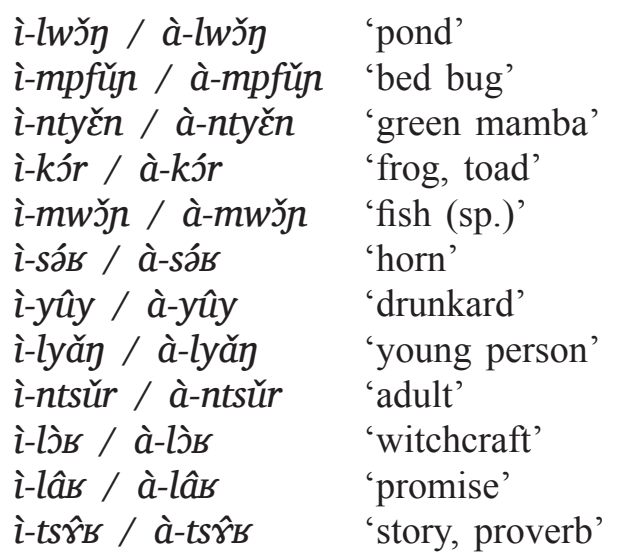

(35) dz-ây / v'-ân 'palm leaf'

$d z$-ân / v-ân 'name, word, speech'

$d z$-ân / v-ân 'tooth'

$d z$-în / $v$-în 'footprint'

$d z$-ǐn / v-ǐn 'abscess, tumor'

$d z-u ̌ \eta ~ / ~ v '$-ŭg 'body'

$d z$-ây / v-ây 'eye'

$d z$-îb / v-îb 'house'

$d z$-îm / v-îm 'pregnancy'

$d z-\hat{\imath} r / v$-îr 'yam (sp.)'

$d z$-ǔy / $v^{y}$-ǔy 'savanna'

The agreement patterns of 5/6 nouns are shown in (36)-(43).

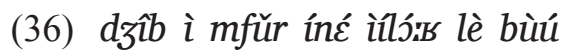

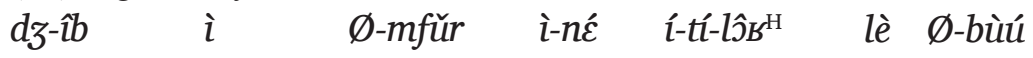

CL5-house 5.CONN CL7Ø-bird 5-this s5-PRF-fall in CL7Ø-soil

'This nest (lit. house of the bird) has fallen on the ground.'

(37) vîb à mfǔr ánć àt’ó: lè bùú

$v$-îb à $\quad \emptyset$-mfǔr $\quad \grave{a}-n \varepsilon^{2} \quad a$-tí-lôs $b^{\mathrm{H}} \quad l e ̀ \quad \emptyset$-bùú

CL6-house 6.CONN CL8Ø-bird 6-this s6-PRF-fall in CL7Ø-soil

'These nests (lit. house of the birds) have fallen on the ground.' 
(38) ìsăg i $d z \hat{u} b$

ì-săn

$\grave{i} \quad \emptyset-d z u \hat{u} b$

CL5-cloth 5.CONN CL8Ø-upstream

'shirt (lit. cloth of upstream)'

(39) àsăn á Đgié

à-săn

à $\quad \emptyset$-ggié

CL6-cloth 6.CONN CL8Ø-downstream

'trousers (lit. clothes of downstream)'

(40) ìmǔn $\emptyset$ óndíe ínínên ìné

ì-mŭn ì ò-ndíé ì-nínên ì-né

CL5-chikwangue 5.CONN CL3-white.man 5-big:INT 5-this

'this big bread (lit. chikwangue of white man)' 14

(41) àmǔn $\emptyset$ éndié ánîn ànínên

à-mǔn à $\quad \grave{e}$-ndíé à-nîn à-nínên

CL6-chikwangue 6.CONN CL4-white.man 6-four 6-big:INT

'four big breads (lit. chikwangue of the white men)'

(42) ìbwว̌n íyúò l' àvâm

i-bwว̌n

$i-\emptyset-y u ́ o^{\mathrm{HL}}$

là à-vôm

CL5-raphia.bag s5-GEN.PRs-be.full with cL6-thing

'the raphia bag is full of things.'

(43) àbwว̌n áyúò l’ àvâm

à-bwว̌n

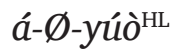

là à-vâm

CL6-raphia.bag s6-GEN.PRs-be.full with cL6-thing 'the raphia bags are full of things.'

\subsubsection{Class pairing $7 \mathrm{e} / 8 \mathrm{i}$}

Nouns in class pairing 7e/8i take $\grave{e}$ - in the singular and $\grave{i}$ - in the plural. As shown in (44), semantically, CL7e/8i nouns denote body parts, human qualities and relations, plant-related products, objects, some animal

${ }^{14}$ Chikwangue, also known as kwanga, is a bitter fermented dough of manioc which is a staple food in the DRC and other Central and West African countries. 
species (especially small mammals, birds and fish), religion and witchcraft-related terms. This is also the class pairing used to count, see (45).

\section{(44)}

$\grave{e}-t \hat{r} r$ / ì-tôr

è-tûn / ì-tûn

è-tsûb / ì-tsûb

$\grave{e}$-tş́r / ì-tsŕs

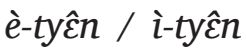

è-jnîm / ì-nîm

$\grave{e}-k \hat{u} y$ / ì-kûy

è-ntsôn / ì-ntsồn

è-pfûy / ì-pfûy

è-púó / ì-púó

è-fúù / ì-fúù

è-vâr / ì-vâr

è-wûr / ì-wûr

è-téám / ì-téám

$\grave{e}-s \hat{a} \beta$ / ì-sâa

$\grave{e}-s \hat{a} b$ / ì-sâb

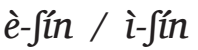

è-lûn / ì-lûn

è-lăb / ì-lăb

è-lغ̀ám / ì-lèám

$\grave{e}-p \hat{\gamma} B / \grave{i}-p \hat{\gamma} B$

è-kân / ì-kân

è-kăr / ì-kăr

è-túò / ì-túò

(45) è-môr 'one'

i-pò 'two'

ìsâr 'three'

ì-nîn 'four'

ì-téàn 'five' 'well'

'enemy'

'banana bunch'

'orphan'

'spell, evil eye'

'spirit of the dead'

'itch'

'shame'

'calabash'

'badness'

'foam'

'field'

'friend, comrade'

'antelope (sp.)'

'bladder'

'fishing basket'

'squirrel'

'face, forehead'

'promise, commitment date'

'clothes'

'liver'

'taboo'

'bird (sp.)'

'blister' 


\section{ì-sôm 'six' \\ i-fámbyà 'seven' \\ ì-nèàní 'eight' \\ ì-wùá 'nine'}

The agreement patterns of nouns in class pairing 7e/8i are shown in (46)-(52).

(46) èvâr ènínĉn élí l'òkûn

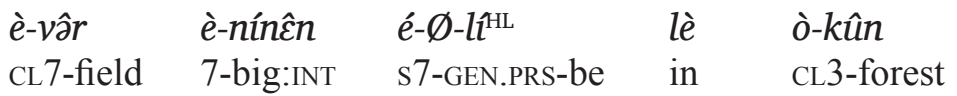

'the big field which is in the forest (lit. the big field is in the forest).'

(47) ìvâr ìsâr ìnên

ì-vâr ì-sâr ìn

CL8-field 8-three 8-big

'three big fields'

(48) síyâr è/ìlèám

sí-Ø-yárá $\quad$ è-/ì-lèám

S1PL-GEN.PRS-tear CL7-/CL8-cloth

'I (usually) tear the cloth(es).'

(49) síyòyárà

sí- Ø-ò-yárá ${ }^{\mathrm{HL}}$

S1PL-GEN.PRS-O.SG-tear

'I (usually) tear it (the cloth).'

(50) síyàyárà

sí-Ø-à-yárá ${ }^{\mathrm{HL}}$

S1PL-GEN.PRS-O.PL-tear

'I usually tear them (the clothes).'

(51) èsâb è wèár mé èíbiá

$\grave{e}$-sâb $\quad \grave{e} \quad \varnothing$-wèár $\quad \varnothing \quad m \varepsilon \quad e$-tí-bíá

CL7-fishing.basket 7.CONN CL1Ø-wife 1Ø.CONN 1sG s7-PRF-be.worn.out 'The fishing basket of my wife has become worn out.' 
(52) ìsấ $\emptyset$ àvèár á sú ì̌bíá

ì-sâb ì à-vèár à sú i-tí-bíá ${ }^{\mathrm{H}}$

CL8-fishing.basket 8.CONN CL2-wife 2.CONN 1PL s8-PRF-be.worn.out 'The fishing baskets of our wives have become worn out.'

\subsubsection{Class pairing $7 \varnothing / 8 \varnothing$}

Nouns in this class pairing take a zero prefix in the singular and plural. We label this pairing $7 \varnothing / 8 \varnothing$ because these nouns trigger the same agreement as $7 \mathrm{e} / 8 \mathrm{i}$ and $7 \mathrm{e} / 8 \mathrm{~N}$ nouns. As can be seen in (53), most $7 \varnothing / 8 \varnothing$ nouns start with a homorganic nasal. This suggests that they historically belonged to $\mathrm{PB}$ class pairing $9 / 10$ whose noun class prefixes are reconstructed as ${ }^{*} N-/ * N$ - (see $\S 4$ for further discussion). Semantically, nouns in this class pairing designate animals (especially mammals, reptiles and birds), diseases, plant species (including mushrooms), objects, places, natural elements, human-related activities, relations, qualities and feelings, and body parts. ${ }^{15}$

\begin{tabular}{|c|c|}
\hline Ø-dzùó / Ø-dzùó & 'civet cat' \\
\hline$\emptyset$-mbûr / Ø-mbûr & 'goat' \\
\hline$\emptyset$-mfûr / $\emptyset$-mfûr & 'land turtle' \\
\hline Ø-ntfúè / Ø-ntfúè & 'electric fish' \\
\hline 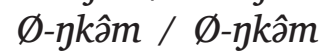 & 'monkey' \\
\hline 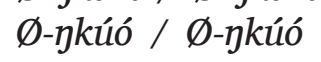 & 'snail, cowry' \\
\hline Ø-ngùú / Ø-ngùú & 'hippopotamı \\
\hline
\end{tabular}

${ }^{15}$ Two anonymous reviewers suggest that nouns labelled as $7 \varnothing / 8 \varnothing$ should be labelled 9/10. As we discuss in $\$ 4$, in Ngwi, the agreement patterns of PB CL7 *kì- and CL9 *jì- merged to $\grave{e}$ - while the agreement patterns of PB CL8 *bì- and CL10 *ji- merged to $i$-. Thus, what we label synchronically as $7 \varnothing / 8 \varnothing$ is the result of this historical merger. We see no good reason to prefer the label 9/10. In fact, the labelling $7 \varnothing / 8 \varnothing$ is synchronically transparent and less prone to confusion given that the prefixless class $7 \varnothing / 8 \varnothing$ triggers exactly the same agreement as $7 \mathrm{e} / 8 \mathrm{i}$ nouns which have noun class prefixes that are direct reflexes of PB CL7 kì$(>\grave{e}-)$ and PB CL8 bì- $(>\grave{i}-)$. 


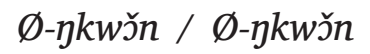

$\emptyset$-ntfûm / Ø-ntfûm

$\emptyset-\nu^{y} \hat{\varepsilon} y / \varnothing-\nu^{y} \hat{\varepsilon} y$

$\emptyset$-ntfûy / Ø-ntfûn

$\emptyset$-tìi / $\emptyset$-tìi

$\emptyset$-mbwว̌m / Ø-mbwว̌m

$\emptyset-\nu^{y} \hat{\varepsilon} y / \emptyset-\nu^{y} \hat{\varepsilon} y$

$\emptyset$-wว̌m / wǒm

$\emptyset$-ndzìa / Ø-ndzìa

$\emptyset$-mbǔm / Ø-mbǔm

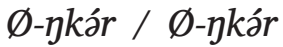

$\emptyset$-ntsóm / Ø-ntsóm

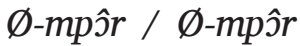

$\emptyset$-ntûm / Ø-ntûm

$\emptyset$-tfía / Ø-tfía

$\emptyset$-mvúyè / Ø-mvúyè

$\emptyset$-ndzăr / Ø-ndzăr

Ø-mbû́ / Ø-mbû́

$\emptyset$-ndwว̌n / Ø-ndwว̌

Ø-lî̀ / Ø-lî̀

Ø-mbèán / Ø-mbèán

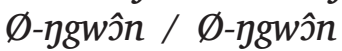

Ø-ndúè / Ø-ndúè

Ø-móm / Ø-móm

Ø-ndŝb / Ø-ndŝb

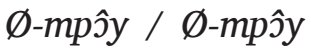

$\emptyset$-dzià / Ø-dzìà

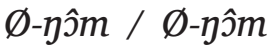

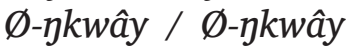

$\emptyset$-ntèán / Ø-ntèán

$\emptyset$-mbî̀ / Ø-mbî̀

Ø-lîm / Ø-lîm

$\emptyset$-lwว̌n / Ø-lwว̌

$\emptyset$-vìu / Ø-vìu 'crocodile'

'wild boar'

'hair'

'buttocks'

'excrements'

'nose'

'tear'

'fear'

'hunger'

'elephantiasis'

'fever'

'eldest child'

'coward'

'messenger'

'fire'

'rain, year'

'thunder'

'path'

'marsh'

'stream'

'virgin forest'

'moon'

'reed (sp.)'

'yam (sp.)'

'fish hook'

'week'

'garbage dump'

'drum'

'chair'

'bed, mat'

'back, rear'

'song'

'sleep'

'mushroom (gen.)' 
The agreement patterns of CL7Ø/8Ø nouns are shown in (54)-(61).

(54) kyع́j ékúù èné

$\begin{array}{llll}\emptyset \text {-kyén } & \grave{e} & \grave{e}-k u ́ u ̀ ~ & \grave{e}-n \dot{\varepsilon} \\ \text { CL7Ø-bracelet } & \text { 7.CONN } & \text { CL7-leg } & \text { 7-this } \\ \text { 'this ankle ring (lit. bracelet of the leg) } & \end{array}$

(55) kyćn i pkín ísôm

$\emptyset$ Øyर́ं $\quad$ i

i $\quad \emptyset$-nkín ì-sôm

CL8Ø-bracelet 8.CONN CL8Ø-neck 8-six

'six necklaces (lit. bracelets of the necks)'

(56) ndzc̀ám é bùú

$\emptyset$-ndzغ̀ám $\quad \grave{e} \quad \emptyset$-bùú

CL7Ø-god 7.CONN CL7Ø-earth

'parent (lit. god of the earth)'

(57) ndzغ̀ám í bùú

Ø-ndzčám ì $\quad \emptyset$-bùú

CL8Ø-god 8.CONN CL7Ø-earth

'parents (lit. gods of the earth)'

(58) ţ̂̀ èídzárm

Ø-tjíá é-tí-dzâm ${ }^{\mathrm{H}}$

CL7Ø-fire s7-PRF-extinguish

'The fire has been / is extinguished.'

(59) ţi iı́dzám

Ø-ţíá i-tí-dzâm ${ }^{\mathrm{H}}$

CL8Ø-fire s8-PRF-extinguish

'The fires have been / are extinguished.'

(60) síyò áì

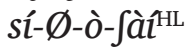

S1PL-GEN.PRS-O.SG-chop

'We (usually) chop it (dead pig) up.'

(61) síyàfáì

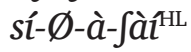

S1PL-GEN.PRS-O.PL-chop

'We (usually) chop them (dead pigs) up.' 
A remarkable feature of Ngwi is that nouns denoting mammals, birds, reptiles, and insects (mostly found in noun class pairing $7 \varnothing / 8 \varnothing$ but also in $3 / 4$ and 5/6) can optionally take human subject indexes of CL2 in the plural, as shown in (64) and (65). However, in the singular, nouns referring to animals must take a human subject index instead of the index of their own class, as can be seen by comparing (62) with the ungrammaticality of (63).

(62) mvûy àíwá

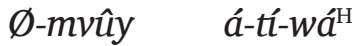

CL7Ø-pig s1-PRF-die

'The pig has died / is dead.'

(63) **mvûy è̀́wá

$\emptyset$-mvûy $\quad \dot{e}-t^{\prime}-w a^{\mathrm{H}}$

CL7Ø-pig s7-PRF-die

intended: 'The pig has died / is dead.'

(64) mvûy ìíwá

$\emptyset$-mvûy $\quad$ i-tí-wá ${ }^{\mathrm{H}}$

CL8Ø-pig S8-PRF-die

'The pigs have died / are dead.'

(65) mvûy wàíwá

Ø-mvûy $\quad$ wá-tí-wá ${ }^{\mathrm{H}}$

CL8Ø-pig s2-PRF-die

'The pigs have died / are dead.'

\subsubsection{Class pairing $7 \varnothing / 2$}

As shown in (66), all 7Ø/2 nouns denote human referents, especially kinship terms and social roles. $7 \varnothing / 2$ nouns take $\varnothing$ - in the singular and $\grave{a}$ - in the plural. Even though they belong to CL7Ø in the singular, they trigger the same subject and object indexes as human-denoting CL1 nouns, see, e.g., (67). 
(66)

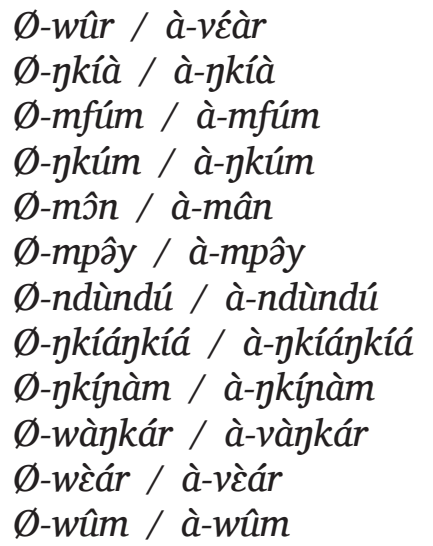

'person'16
'owner'
'slave'
'chief'
'child'
'uncle'
'grandparent'
'paternal aunt'
'younger sibling'
'nephew'
'wife'
'husband'

Two things are noteworthy in terms of form. First, most nouns in (66) start with a homorganic nasal. As we explain in $\S 4$, this nasal likely originates in the fossilization of the prefixes of PB CL9/10 pairing, i.e. ${ }^{*} \grave{N}-/{ }^{*} \grave{N}-$, on the noun root. Second, several nouns in (66) not starting in a nasal display a peculiar first consonant alternation $w$ - $\sim v$ - in their singular and plural root forms (e.g. Ø-wèár / à-vèár) or have a suppletive plural, see e.g. $\emptyset$-wûr / à-véàr. The processes which might have created this consonant alternation and/or suppletivism are not understood at present. The agreement patterns of $7 \varnothing / 2$ nouns are shown in (67)-(72).

(67) wûr èpôr ènć àívárr

\begin{tabular}{|c|c|c|c|}
\hline$\emptyset$-wûr & $\grave{e}$-pôr & $\grave{e}-n \hat{\varepsilon}$ & $a ́-t i ́-v \partial \hat{r}{ }^{\mathrm{H}}$ \\
\hline CL7Ø-person & 7Ø-black & 7Ø-this & s1-PRF-lie.down \\
\hline
\end{tabular}

(68) àvéàr àpôr àsâr àné wàívár
à-véàr

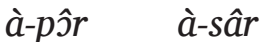
$\grave{a}-n \hat{\varepsilon}$
$w a ́-t i ́-v a ̂ r^{H}$
CL2-person 2-black 2-three 2-this s2-PRF-lie.down
'These three black people are sleeping (lit. have lain down).'

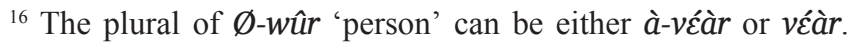


(69) wûm $\eta k \hat{s}$
$\emptyset$-wûm
$\varnothing$

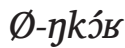
CL7Ø-husband 7Ø.conN CL7Ø-chicken

'rooster (lit. husband of chicken)'

(70) àwûm à $\eta k o ́ b$

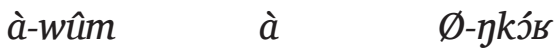

CL2-husband 2.CONN CL8Ø-chicken

'roosters (lit. husbands of chickens)'

(71) gkúm é wì ónć

$\begin{array}{llll}\emptyset \text { - } \eta k \text { úm } & \grave{e} & w \text {-ìa } & \grave{o} \text {-nर́ } \\ \text { CL7Ø-chief } & 7 \varnothing \text {.conN } & \text { CL3-village } & 3 \text {-this } \\ \text { 'the chief of this village' } & & \end{array}$

(72) ànkúm á vì éné

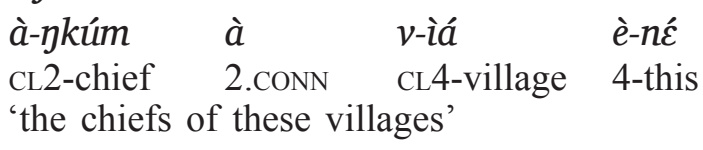

As shown in Table 3 , some $7 \varnothing$ nouns, such as $\emptyset$ - $\eta$ kúm 'chief' in (71) and $\emptyset$-mfúm/à-mfúm 'slave', trigger an $e$ connective, while others such as $\emptyset$-wûm 'husband' in (69) and most other kinship terms trigger a $\emptyset$ connective. As we observed for $1 / 2$ nouns in $\S 3.1 .1$, this alternation is lexically specified for each noun, i.e. it is not ruled by a particular conditioning environment. As was the case for $1 / 2$ nouns, some $7 \varnothing$ nouns allow only $e$ as a connective (e.g. $\emptyset$-mfúm é $m \varepsilon \dot{\varepsilon}$ 'my slave'), some only $\emptyset$ (Ø-wûm $\emptyset m \varepsilon \dot{\varepsilon}$ 'my husband'), while some allow both

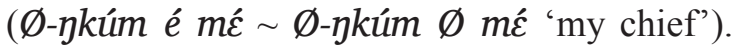

The $7 \varnothing / 2$ nouns in (73) display archaic heterogeneity in that they can form their plural in wà- besides à-. Presumably, wà- is more archaic than $\grave{a}$-. The noun for 'animal' stands out among others in (73) because it makes its plural in either wà- or $\emptyset$-. Other sources (Nsumuki 1993: 12) only report à- as the plural class of the nouns for 'mother', 'father' and 'older sibling' in (73). 
(73)

\begin{tabular}{|c|c|}
\hline Ø-mìá / (w)à-mìá & 'mother' \\
\hline$\emptyset$-tiá / (w)à-tiá & 'father' \\
\hline$\emptyset$-zìi / (w)à-zìi & 'older sibling' \\
\hline$\emptyset$-mòlî̀ / (w)à-mòlû̀ & 'brother-in-law' \\
\hline Ø-lón / (w)à-lón & 'teacher, master' \\
\hline Ø-лâm / (wà)-nâ & 'animal' \\
\hline
\end{tabular}

Remarkably, when the nouns in (73) optionally form their plural in $w a ̀-$ they trigger NP agreement morphemes virtually identical to those of CL8. Exceptions are the connective, which for wà- plural nouns can be either $\grave{i}$ or $\emptyset$, cf. (77) and (79), and the subject index, which for wà- plural nouns is the same as that of CL2, cf. (81). The agreement patterns triggered by the nouns in (73) in their plural wà- form are shown in (74)-(81).

(74) tì é wéàr mé

$\begin{array}{lllll}\emptyset \text {-tiá } & \grave{e} & \emptyset \text {-wéàr } & \emptyset & m \dot{\varepsilon} \\ \text { CL7Ø-father } \quad 7 \varnothing . \text { CONN } & \text { CL7Ø-wife } & 7 \varnothing . \text { CONN } & 1 \text { SG } \\ \text { 'the father of my wife' } & & & \end{array}$

(75) wàtì í wámólî̀ sú

$\begin{array}{lllll}\text { wà-tiá } & \grave{ } & \text { wà-mòlî̀ } & \emptyset & \text { sú }\end{array}$

CL2-father 8.CONN CL2-brother.in.law 2.CONN 1PL

'the fathers of our brothers in law'

(76) tiá mé
$\emptyset$-tiá
$\emptyset \quad m \varepsilon$
CL7Ø-father
7Ø.CONN $1 \mathrm{sG}$
'my father'

(77) wàtiá sú

$\begin{array}{lll}\text { wà-tiá } & \emptyset & \text { sú } \\ \text { CL2-father } & \text { 2.CONN } & 1 \mathrm{PL} \\ \text { 'our fathers' } & & \end{array}$

(78) lón è mé
$\emptyset$-lón
$\grave{e} \quad m \varepsilon$
CL7Ø-teacher 7Ø.CONN 1SG
'my teacher' 
(79) wàlón ì sú

\begin{tabular}{lll} 
wà-lón & \multicolumn{1}{l}{} & sú \\
CL2-teacher & 8.CONN & $1 \mathrm{PL}$ \\
'our teachers'
\end{tabular}

(80) tiá mé álí lè ndwว̆y

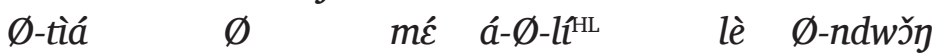

CL7Ø-father 7Ø.CONN 1SG s1-GEN.PRs-be in CL7Ø-marsh

'My father is in the marsh.'

(81) wàtiá sú wáyàtúbà wố là wôs

wà-tiá $\quad \emptyset$-sú wá-yà-túbát ${ }^{\mathrm{HL}} \quad$ wôb là $\quad w \hat{b} b$

CL2-father 2-1PL s2-PRS.PROG-talk 3PL.LF with 3PL.LF

'Our fathers are talking to each other.'

The noun for 'animal' Ø-nâm / wà-nâm always triggers human subject agreement in its singular form, as in (82) (see also (62)-(63)). When this noun takes wà- in the plural, subject agreement is the same as that of CL2 human nouns as in (83). When it takes $\emptyset$ - in the plural, subject agreement is the same as that of CL8, as in (84).

(82) jâm è mé àíwá

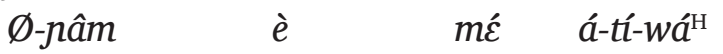

CL7Ø-animal 7Ø.CONN 1SG s1-PRF-die

'My animal has died / is dead.'

(83) wànâm ì sú wàíwá

wà-nâm ì sú wá-tí-wá ${ }^{\mathrm{H}}$

CL2-animal 8.CONN 1PL S2-PRF-die

'Our animals have died / are dead.'

(84) nâm ì sú ì̌wá
$\emptyset$-nâm
$\grave{\imath}$
sú $\quad i-t i ́-w a a^{\mathrm{H}}$
CL8Ø-animal 8.CONN 1PL S8-PRF-die
'Our animals have died.' 


\subsubsection{Class pairing $7 \mathrm{e} / 8 \mathrm{~N}$}

Nouns in this class pairing take $\grave{e}$ - in the singular and a homorganic nasal $\grave{N}$ - in the plural which triggers the same agreement as subclasses $8 \mathrm{i}$ and $8 \varnothing$ nouns. This is why we label the plural class $8 \mathrm{~N}$. As shown in (85), nouns in this class refer to animal and human body parts, plant species and products, animals (especially insects, birds, and shellfish), diseases, irregular body conditions, substances, objects, natural elements, parts of the day, and speech acts, among others.

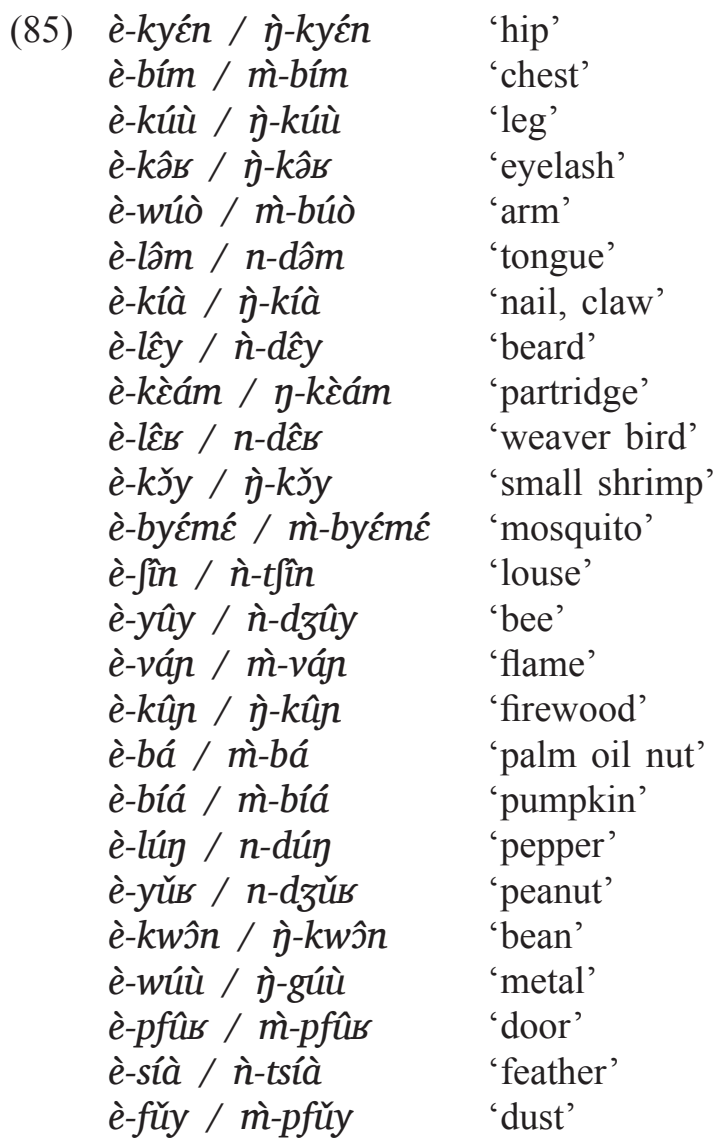



è-fúù / ’̀-tfúù
'day'
è-kùó / ì-kùó
'sunset'
è-pór / mì-pór
'scabies'
è-bùú / m̀̀-bùú
'pimple'
è-kâr / ’̀̀-kâr
'hernia'
è-wì̀ / j̀̀-gwì
'anthill'
è-wú / m̀-bú
'affair'

The agreement patterns of $7 \mathrm{e} / 8 \mathrm{~N}$ nouns are shown in (86)-(89).

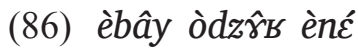
è-bây
$\grave{e}$
$\grave{o}-d z \hat{\gamma} B$
$\grave{e}-n \varepsilon$
CL7-bamboo 7.CONN
CL3-poison 7-this
'this poisonous arrow'

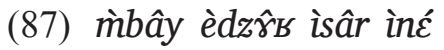

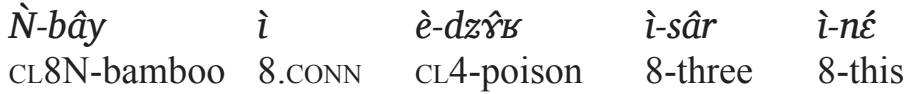

'these three poisonous arrows'

(88) èkây è ndăb é mvá élí òkyâb

\begin{tabular}{|c|c|c|c|c|}
\hline$\grave{e}$-kây & & $\emptyset$-ndə̌b & $\grave{e}$ & Ø-mvúá \\
\hline eaf & 7.CONN & cL7Ø-bell & 7.CONN & CL7Ø-dog \\
\hline$e=\varnothing-l \imath^{\mathrm{HL}}$ & ò-kyâb & & & \\
\hline
\end{tabular}

'The leaf of the tree (sp.) is small. ${ }^{17}$

(89) jkây è ndăb è mvá illí èkyâb

\begin{tabular}{|c|c|c|c|c|}
\hline Ǹ-kây & $\grave{e}$ & $\emptyset$-ndǎb & $\grave{e}$ & Ø-mvúá \\
\hline$i-\varnothing-l \imath^{\mathrm{HL}}$ & $\grave{e}-k y \hat{a} b$ & & & \\
\hline
\end{tabular}

${ }^{17}$ The free translation reads 'tree (sp.)' because we are currently unable to provide a scientific name for this tree species. The tree called ndǎb é mvá (literally 'bell of the dog') is used by the Ngwi people to make hunting bells for dogs. 


\subsubsection{Class pairing $11 / 8 \mathrm{~N}$}

$11 / 8 \mathrm{~N}$ nouns take $\grave{o}-$ in the singular and a homorganic nasal $\grave{N}$ - in the plural which triggers the same agreement as other CL8 nouns. All 11/8N nouns in our database are in (90). We consider CL11 as separate from CL3 for two reasons: they take distinct subject index (see Table 3), and they take different plural pairings (CL3 only makes its plural in CL4 and CL11 only makes its plural in CL8N), see Kadima's (1969) criteria (i) and (iii) in $\S 3$. There is evidence that $11 / 8 \mathrm{~N}$ nouns are shifting to class pairing 3/4, in which case the singular has $\grave{o}$ - instead of $\grave{e}$ - as a subject index and the plural takes $\grave{e}$ - as a noun class prefix instead of a homorganic nasal. Pairing 3/4 is often given as an alternative noun class pairing in elicitation for some of the nouns in (90).

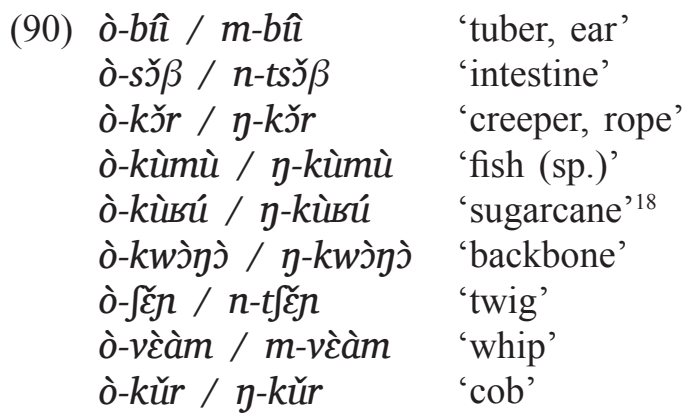

The agreement patterns of $11 / 8 \mathrm{~N}$ nouns are in (91)-(96).

(91) òkǒr ó vân òné

\begin{tabular}{|c|c|c|c|}
\hline ò-kǒr & ó & $v$-ân & $\grave{o}-n \varepsilon$ \\
\hline
\end{tabular}

${ }^{18}$ This is a borrowing, possibly from Kikongo Ya Leta a lingua franca used in the region where Ngwi is spoken. The autochthonous Ngwi word for sugar cane is ò-fûy / ̀̀-fûy (CL3/4). 


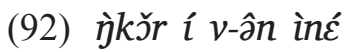

$\grave{j}$-kǒr $\quad \grave{\imath} \quad v$-ân $\quad \grave{n} n \varepsilon$

CL8N-rope 8.conN CL6-tooth 8-this

'these toothbrushes (lit. ropes of the teeth)'

(93) òfร̌n ótitîy òné

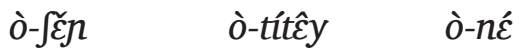

CL11-twig 11-long:INT 11-this

'this long twig'

(94) nt f̌̌n ífámbyà itútêy

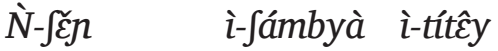

CL8N-twig 8-seven 8-long:INT

'seven long twigs'

(95) òbí ìntú ónć élí òkyâb

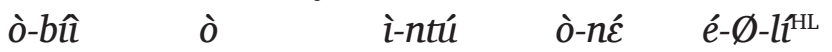

CL11-ear 11.CONN CL5-corn 11-this s11-GEN.PRS-be

$\grave{o}-k y a ̂ b$

CL3-smallness

'This ear of corn is small.'

(96) m̀̀bí àntú íné ilí èkyâb

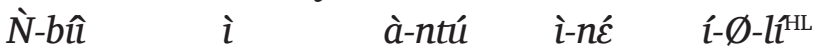

CL8N-ear 8.CONN CL6-corn 8-this s8-GEN.PRS-be

$\grave{e}-k y a ̂ b$

CL4-smallness

'These ears of corn are small.'

\subsection{Marginal noun class pairing}

Synchronically, there is only one marginal class pairing in Ngwi, i.e. $7 / 6$. We consider it marginal because it only contains two nouns: è-pfún / à-pfún 'testicle' and Ø-vâm / à-vâm 'thing'. These nouns take $\grave{e}$ - or $\emptyset$ - in the singular and $\grave{a}$ - in the plural. The agreement patterns of nouns in this class pairing are in (97)-(102). Even if this class pairing is on its way out synchronically, it can nevertheless be informative from a diachronic perspective. 
(97) vâm è $\eta k u ́ m$

$\emptyset$-vâm $\quad \grave{e} \quad \emptyset$-nkúm

CL7Ø-thing 7.CONN 7Ø-chief

'the thing of the chief'

(98) àvâm à $\eta k u ́ m$

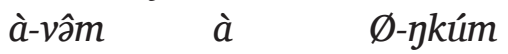

CL6-thing 6.ConN 7Ø-chief

'the things of the chief'

(99) àvâm àsâr àné àil’ó:

à-vâm à-sâr à-nên á-tí-lô, ${ }^{\mathrm{H}}$

CL6-thing 6-three 6-big s6-PRF-fall

'Three big things have fallen.'

(100) vâm èné èilló:

$\emptyset$-vâm $\grave{e}-n \dot{\varepsilon} \quad \dot{e}-t \underline{-}-l \hat{\partial} B^{\mathrm{H}}$

CL7Ø-thing 7-this S7-PRF-fall

'This thing has fallen.'

(101) èpfún é wûm ggwóm
$\grave{e}$-pfún
$\grave{e}$
$\emptyset$-wûm
$\emptyset$
$\emptyset$ -
CL 7-testicle 7 .cONN
CL7Ø-husband 7Ø.conN
CL7Ø-cattle 'the testicle of the bull'

(102) àpfún á wûm நgwóm
à-pfún
$\grave{a}$
$\emptyset$-wûm
$\varnothing$
$\emptyset$-пgwóm
CL6-testicle CL6.CONN CL7Ø-husband 7Ø.CONN
CL7Ø-cattle
'the testicles of the bull'

\subsection{Mono-class nouns}

The following subsections discuss nouns which have only a singular form, either in CL3 or CL7e/7Ø, and nouns which have only a plural form, either in CL6 or CL8Ø.

\subsubsection{Class 3}

Nouns in CL3 refer to feelings and other non-physical conditions, as well as body and sensory conditions (103). 


\begin{tabular}{|c|c|c|}
\hline (103) & $\grave{o}-l \check{c} m$ & 'tiredness' \\
\hline & ò-lûy & 'sky' \\
\hline & ò-lúù & 'bitterness' \\
\hline & ò-nêy & 'acidity' \\
\hline & $\grave{o}-s \hat{\varepsilon} r$ & 'slipperiness' \\
\hline & ò-wôy & 'attention' \\
\hline & $\grave{o}-m \hat{a ̂ b}$ & 'twenty' \\
\hline & ò-ntsûn & 'shyness' \\
\hline & ò-ntyên & 'wisdom' \\
\hline & ò-sćày & ‘joy’ \\
\hline & ò-sûb & 'attention' \\
\hline & ò-zíà & 'knowledge' \\
\hline
\end{tabular}

The agreement patterns triggered by CL3 nouns are shown in (104)-(105).

(104) òsćàn ò môn
ò-sćàn $\quad \grave{o}$
CL3-joy 3.conN
$\emptyset$-môn
CL7Ø-child

'The joy of the child'

(105) òlûy òíyúó là màfùbà
ò-lûy ó-tí-yúô $\quad$ là $\quad \emptyset$-màfùbà
CL3-sky s3-PRF-be.full with CL8Ø-cloud
'The sky is cloudy (lit. the sky is filled with clouds).'

\subsubsection{Class 6}

As is common in Bantu and Niger-Congo languages more generally, this class contains liquids and uncountable nouns. Just like cL6 nouns which make their plural in CL5 (see \$3.1.3), mono-class 6 nouns take $\grave{a}$ - if the noun root starts in a consonant (106), and $v$ - if the noun root starts in a vowel (107).

(106) à-kćy 'sexual intercourse'

à-lúy 'blood' 


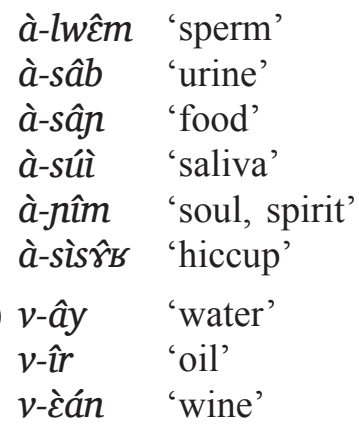

The agreement patterns of CL6 nouns are shown in (108)-(109).

(108) vîr à nâm ákíè
$v$-îr
à
Ø-лnâm
á-Ø-kíè $\mathrm{HL}$
CL6-fat 6.CONN
CL7Ø-animal s6-GEN.PRS-melt
'The animal fat melts.'

(109) àsúì à ndzúà àpôr

à-súi $\quad \grave{a} \quad \emptyset$-ndzúà à-pôr

CL6-saliva 6.CONN CL7Ø-snake 6-black

'black venom (lit. saliva of the snake)'

\subsubsection{Class 7e/7Ø}

Nouns in this class can take either $\grave{e}$ - or $\varnothing$ - as in (110). They refer to uncountable entities, man's (non)-physical attributes and states. Their agreement patterns are shown in (111).
(110) è-kár 'money'
è-lûn 'reason'
è-jîm 'breath'
è-vûb 'healing'

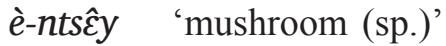
è-tá 'fetish, medicine'
è-téàn 'first, before, ancestral' 


$$
\begin{array}{ll}
\text { è-tùò } & \text { 'laughter' } \\
\text { è-wá } & \text { 'death' } \\
\emptyset \text {-vŭn } & \text { 'sun' }
\end{array}
$$

(111) èkár é ykúm è̃fúr
è-kár
$\grave{e}$
$\emptyset$-ıkúm
é-tí-Jîr ${ }^{\mathrm{H}}$
CL7-money 7.CONN
CL7Ø-chief
S7-PRF-finish

'The money of the chief is finished.'

\subsubsection{Class $8 \varnothing$}

Nouns in this class refer to materials, substances, feelings, and quantities among others, see (112). They take a zero prefix and trigger cL8 agreement patterns as shown in (113)-(115).

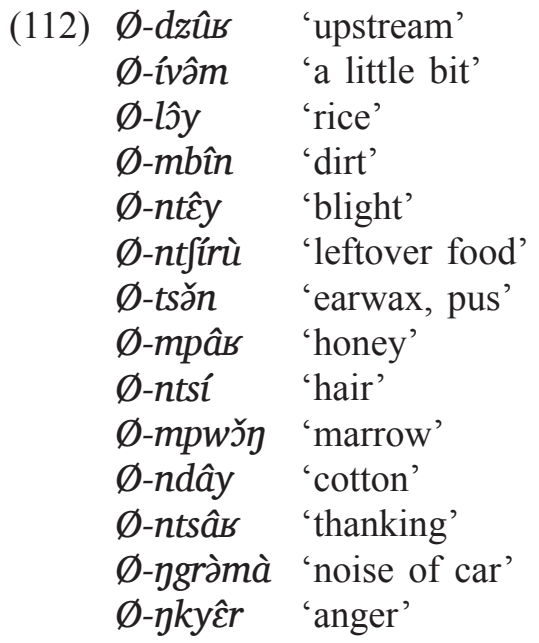

(113) ntsí í dzây

$\emptyset$-ntsí i $\quad d z$-ây

CL8Ø-hair 8.CONN CL5-eye

'eyelash (lit. hair of the eye)' 
(114) ntsí í vây

$\begin{array}{lll}\emptyset \text {-ntsí } & \grave{i} & v \text {-ây } \\ \text { CL8Ø-hair } & \text { 8.CONN } & \text { CL6-eye } \\ \text { 'eyelashes (lit. hair of the eyes)' }\end{array}$

(115) lôy lè mpǔb ìtípwǒn

Ø-lôy $\quad$ lè $\emptyset$-mpǔs i-tí-pwǒn ${ }^{\mathrm{H}}$

CL8Ø-rice in CL7Ø-pot s8-PRF-rot

'The rice in the pot has/is rotten.'

\section{A diachronic account of the Ngwi noun class system}

In this section we discuss the main phonological and morphological changes responsible for the restructuring of the Ngwi noun class system with respect to PB. Table 5 shows the PB noun class and agreement prefixes (Meeussen 1967: 97) and their synchronic reflexes in Ngwi (see Table 3). What we call NP agreement prefixes in Ngwi (abbreviated as NPAP in Table 5) are called pronominal prefixes (PP) by Meeussen (1967). The symbol - means absence of a synchronic reflex. N/A means 'does not apply'.

As can be seen from Table 5, PB classes 12, 13, and 15-19 were lost in Ngwi. The remainder of PB noun class prefixes survived, but underwent important changes in form which led to major restructuring. These changes in prefix shape are twofold: (i) the loss of initial consonants, and (ii) the lowering of PB ${ }^{*} I$ to $/ \mathrm{e} /$ and $\mathrm{PB}{ }^{*} U$ to $/ \mathrm{o} /$. Interestingly, both of these changes are largely specific to the noun class system and mostly at odds with regular diachronic sound changes which affected the Ngwi lexicon. As for the vowels, outside the noun class system, PB * $I$ and $* i$ merged to $/ \mathrm{i} /$ and $\mathrm{PB} * U$ and $* u$ merged to $/ \mathrm{u} /$. However, in the noun class prefixes, $\mathrm{PB}{ }^{*} I$ was lowered to /e/ instead of merging with PB *i, see PB CL4 *mì- > ̀े-, PB CL7 ${ }^{*} k \grave{I}^{-}>\grave{e}-$. In the same vein, $\mathrm{PB}{ }^{*} U$ was lowered to $/ \mathrm{o} /$ instead of merging with PB *u, see PB CL1 and CL3 *mù- > ò-, PB CL11 *dù- > $\grave{o}$-. Although the lowering of the PB near-close vowels ${ }^{*} I$ and ${ }^{*} U$ to $e$ 
and $o$ respectively is common in 7-Vowel Bantu languages of the forest (cf. Grégoire 2003), it is not regularly attested in the Ngwi lexicon.

Table 5

PB and Ngwi noun classes and NP agreement prefixes

\begin{tabular}{|c|c|c|c|c|c|}
\hline \multicolumn{3}{|c|}{ Рroto-Bantu } & \multicolumn{3}{|c|}{ NGWI } \\
\hline class & CL prefix & PP & class & CL prefix & NPAP \\
\hline 1 & *mù- & *jù- & 1 & $\grave{o}-$ & $\grave{o}-$ \\
\hline 2 & *bà- & *bá- & 2 & à-/wà- & $\grave{a}-$ \\
\hline 3 & *mù- & *gú- & 3 & $\grave{o}-/ w-$ & $\grave{o}-$ \\
\hline 4 & *mì- & "gí- & 4 & $\grave{e}-$ & $\grave{e}-$ \\
\hline 5 & $* i-$ & *dí- & 5 & $i-/ d z^{-19}$ & $i-$ \\
\hline 6 & *mà- & *gá- & 6 & $\grave{a}-/ \nu-$ & $\grave{a}-$ \\
\hline 7 & *kì- & *k'́- & $7 \mathrm{e}$ & $\grave{e}-$ & $\grave{e}-$ \\
\hline 8 & *bì- & *bí- & $8 \mathrm{i}$ & $\grave{i-}$ & $i-$ \\
\hline 9 & $* \grave{N}-$ & ${ }^{*} \hat{J I}-$ & $7 \varnothing$ & $\emptyset-\grave{N}^{20}$ & $\grave{e}-$ \\
\hline 10 & $* \grave{N}-$ & $* j i-$ & $8 Ø / 8 \mathrm{~N}$ & $\emptyset-\grave{N} / \grave{N}-$ & $i-$ \\
\hline 11 & *dù- & $* d u^{-}$ & 11 & $\grave{o ̀-}$ & ò- \\
\hline 12 & *kà- & *ká- & - & - & - \\
\hline 13 & *tù- & *tú- & - & - & - \\
\hline
\end{tabular}

${ }^{19}$ The PB class 5 noun prefix is reconstructed as *i- while the "augment" or "pre-prefix" is reconstructed as *dì- (cf. De Blois 1970). In many Bantu languages, these two morphemes inverted their roles, i.e. the historical noun class prefix became the augment and the historical augment became the noun class prefix (cf. Kamba Muzenga 1988). In languages such as Ngwi, the historical noun class prefix *i- $(>i-)$ and the augment $* d i^{-}\left(>d z^{-}\right)$resulted in two allomorphic noun class prefixes.

${ }^{20}$ The reflex of the PB class $9 * \grave{N}$ - was segmentally retained as a homorganic nasal in Ngwi, but its morphological status changed. It is no longer a prefix, but became an integral part of the noun stem. That is why we represent it here without a following hyphen. PB class $10 * \grave{N}$ - partially underwent the same evolution (cf. class $8 \varnothing$ ), but did not entirely lose its morphological status as a prefix (cf. class $8 \mathrm{~N}$ ). 
End of table 5

\begin{tabular}{|c|c|c|c|c|c|}
\hline \multicolumn{3}{|c|}{ Рroto-Bantu } & \multicolumn{3}{|c|}{ NGWI } \\
\hline class & CL prefix & PP & class & CL prefix & NPAP \\
\hline 14 & *bù- & *bú- & 3 & $\grave{o}-/ w-$ & ò- \\
\hline 15 & *kù- & $* k u^{\prime}$ & - & - & - \\
\hline 16 & *pà- & *pá- & - & - & - \\
\hline 17 & *kù- & *kú- & - & - & - \\
\hline 18 & *mù- & N/A & - & - & - \\
\hline 19 & *pì- & $\mathrm{N} / \mathrm{A}$ & - & - & - \\
\hline
\end{tabular}

If one looks at the reduction of $\mathrm{CV}>\mathrm{V}$ in Ngwi noun class prefixes, only the loss of certain consonants can be accounted for as regular sound change. Within the stem, the loss of certain PB consonants is only observed in $\mathrm{C}_{2}$ position. This can therefore be considered as a prosodically less prominent position than $\mathrm{C}_{1}$ in a $\mathrm{C}_{1} \mathrm{~V}_{1} \mathrm{C}_{2} \mathrm{~V}_{2}$ template (see Hyman 1998; 2008). Apart from PB *j, whose phonological status is problematic more generally (Guthrie 1953; cf. Coupez 1954; Meeussen 1967; Wills forthcoming), PB *d is the only consonant attested in PB noun class and agreement prefixes that is systematically reduced to zero in $\mathrm{C}_{2}$ position in Ngwi, while $\mathrm{PB} * \mathrm{*}$ and $* k$ only become $\varnothing$ in $\mathrm{C}_{2}$ in very few Ngwi words (8\%) to the detriment of the more common reflex / / (Pacchiarotti \& Bostoen forthcoming). Other PB consonants, such as ${ }^{*} b$ and ${ }^{*} m$, are almost never reduced to zero in Ngwi, not even in the prosodically less prominent $\mathrm{C}_{2}$ position (Pacchiarotti \& Bostoen 2020). In other words, apart from ${ }^{*} j$ in the NP agreement prefix of classes 1, 9 and 10 (cf. PP in PB in Table 5), only the loss of *d in the prefixes of class 11 can be seen as the outcome of regular sound change, if we posit that the word-initial prefix position is also prosodically less prominent than the stem-initial $\mathrm{C}_{1}$ position. Along the same lines, the loss of PB $* g$ in the NP agreement prefixes of classes 3,4 and 6 and $* k$ in the prefixes of class 7 could be considered as the result of a sound change sporadically attested elsewhere in the language, 
even if $/ \mathrm{b} /$ is by far the most common lenited reflex of PB $* g$ and $* k$ in $\mathrm{C}_{2}$ position in Ngwi. However, the loss of $\mathrm{PB} * m$ and $* b$ in the noun class prefixes of classes 1,3 and 6 and the prefixes of classes 2 and 8 respectively cannot be seen as the result of a sound change attested elsewhere in the language. $\mathrm{PB} * m$ is retained everywhere, while $\mathrm{PB}{ }^{*} b$ is retained in $\mathrm{C}_{1}$ (but can occasionally undergo lenition to $/ \mathrm{w} /$ ) and becomes $/ \beta /$ in $C_{2}$ position (and is sporadically lost). Hence, to account for the almost generalized loss of initial consonants in Ngwi noun class prefixes (except for the very rare cL2 wà-, the phonologically conditioned allomorphs of classes 5 and 6 and the homorganic nasals of erstwhile classes 9 and 10), one needs to posit analogy as an explanation for the changes in prefix shape. We assume that the generalization of V- shapes in Ngwi noun class prefixes to the detriment of residue CV- shapes is the outcome of analogical levelling. Most V-shaped prefixes in the Ngwi NPAP paradigm can be considered as reflexes of PB CV-shaped pronominal prefixes (PP) where ${ }^{*} \mathrm{C}$ was lost through sound changes attested elsewhere in the language (i.e. PB $* d, * j, * g$, and $* k>\emptyset$ ). However, this is not the case for the Ngwi noun class prefix paradigm because the loss of $* m$ in the PB noun class prefixes of classes 1,3 , 4 , and 6 is nowhere attested in Ngwi. Similarly, the loss of $* b$ in the PB noun class prefixes of classes 2 and 14 is usually not attested elsewhere in the language. Conceivably, analogical levelling started out in the inherited PB PP paradigm and extended from there to the inherited PB noun class prefix paradigm, for which a generalized pattern of V- shaped prefixes is much rarer across Bantu (cf. Maho 1999). Even though we cannot substantiate this scenario with empirical evidence, research suggests that noun class prefixes tend to be more conservative than agreement morphology on other constituents of the noun phrase (Kießling 2013; Güldemann \& Fiedler 2019).

Whatever its origin may have been, the generalized loss of initial consonants in Ngwi noun class prefixes considerably increased uniformity in prefix shapes across noun classes. For instance, PB *mù$(1,3)$, *dù- (11) and *bù- all yielded $\grave{o}-$ in Ngwi, PB *bà- (2) and *mà- yielded à-, PB *mì- (4) and *kì- (7) yielded $\grave{e}-$ and PB *ì- (5) 
and *bì- (8) yielded $\grave{i}$-. If the inherited noun class prefixes PB *I and ${ }^{*} U$ had not been irregularly lowered to $e$ and $o$ respectively but had merged with PB * $i$ and * $u$ as elsewhere in the language, the homogeneity of prefix forms would have been even greater. Without irregular lowering, PB CL5 *ì- and CL8 *bì- would have merged with CL4 *mìand CL7 *kì-, so that four distinct morphological classes would have resulted in /i/. Such a merger might have caused communicative inefficiency in the case of classes 7 and 8 , as they form a singular/ plural class pairing. One wonders whether the morphologicallyconstrained lowering of $\mathrm{PB}{ }^{*} I$ and ${ }^{*} U$ in noun class prefixes did not happen to prevent the spread of communication-hindering homophony within the noun class paradigm.

In any event, despite the mergers in prefix shapes, several originally distinct classes are still distinguishable because they pair up (only) with a distinct singular/plural class prefix (e.g. $11 / 8 \mathrm{~N}$ ) or because their agreement prefix paradigms are still (partially) distinct. For instance, as shown in Table 3, Ngwi CL2 à- (< PB *bà-) and CL6 à- (< PB *mà-) are still distinguished by subject indexes, while Ngwi CL1 $\grave{o}-$, CL3 $\grave{o}-$ and CL11 $\grave{o}$ - are distinguished by subject indexes and by the fact that some CL1 nouns trigger a zero connective.

In some cases, the merger of prefix shapes only caused paradigm levelling in NP agreement morphemes without affecting noun class prefixes. This kind of restructuring can be seen in the evolution of $\mathrm{PB}$ CL9 and CL10. As can be seen in Table 5, the agreement prefixes of PB CL7 *kì- and CL9 *jí- merged into $\grave{e}$-. Similarly, the agreement prefixes of PB CL8 *bi- and CL10 *jí- merged into $i-$. While the historical homorganic nasal prefix of CL10 still functions as a commutable noun class prefix of class $8 \mathrm{~N}$ in Ngwi (see $\$ 3.1 .7$ and $\$ 3.1 .8$ ), in all $\mathrm{PB}$ CL9/10 nouns the original homorganic nasal prefix was reanalyzed as part of the simple noun stem. All historical cL9/10 nouns in Ngwi have a frozen homorganic nasal preceding both voiceless and voiced stops in the singular and plural forms of the simple noun stem. Original CL9/10 nouns were reassigned mostly to subclass $7 \varnothing / 8 \emptyset$ and to a lesser extent to pairings $1 / 2$ and $7 \varnothing / 2$. 
In other cases, paradigm levelling in the singular class triggered analogical reanalysis in the plural. This type of restructuring is illustrated by the developments of historical CL14/6 nouns. As shown in (23), nouns belonging to CL14/6 in PB were incorporated into CL3/4 in Ngwi. They kept their original noun class prefixes, PB CL14 *bù- > $w$ - and PB CL6 *mà- $>v$-, which became conditioned allomorphs of synchronic CL3/4 prefixes ò- (< PB CL3 *mù-) and è- (< PB CL4 *mì-) respectively. Probably, the merger of PB CL14 *bù- and PB CL3 *mùand their agreement patterns * $b u$ - and "gú- respectively into $o$ - in Ngwi initially favored the shift of historical CL14 nouns into CL3. However, because PB CL6 agreement patterns *mà- and "gá- did not merge with PB CL4 "mì- and *gì- (see Table 5), the plural of historical cL14/6 must have shifted to CL4 by analogy with CL3, that is, because CL3 nouns make their plural in CL4 in Ngwi.

Before addressing conservative vs. innovative Ngwi noun class pairings, we note the remarkable development of $v$ - as an allomorph of CL6 à- from PB CL6 *mà-. As discussed in $\$ 3.1 .3, v$ - is used when CL4 and CL6 nouns start in a vowel. Nasals (and other sonorants) can become fricatives when devoiced (Ohala \& Solé 2008: 302), i.e. ${ }^{*} m>m_{o}>f$. However, one would still need to explain why * $m$ in PB *mà- became voiceless and then how/why the fricative outcome became voiced (i.e. /v/). In Ngwi, $v$ - occurs only as a noun class prefix whether frozen or synchronically commutable. It also occurs in $\mathrm{C} 1$ position in nouns which have an irregular or suppletive plural such as Ø-wżár / à-vèár 'wife' and Ø-wûr / à-véàr 'person'.

As shown in the subsections of $\S 3.1$, Ngwi retained PB class pairings $1 / 2,1 \mathrm{a} / 2$ (which we call 7Ø/2), 3/4,5/6 and 7/8. All of these class pairings with the exception of $5 / 6$ absorbed a variable amount of nouns historically belonging to other classes. A few historical 9/10 nouns referring to humans were reassigned to $1 / 2$ and $7 \varnothing / 2$. Many synchronic $1 / 2$ nouns in Ngwi must have belonged to CL $9 / 10$ at some point in previous stages of the language, as evidenced by the presence of a frozen homorganic nasal as part of their simple noun stem (see (13)). Many historical $14 / 6$ nouns were incorporated into $3 / 4$ due to analogical 
levelling and reanalysis of the plural class. $\mathrm{PB}$ class pairing $7 / 8$ split into 3 distinct subclasses in Ngwi: $7 \mathrm{e} / 8 \mathrm{i}, 7 \varnothing / 8 \varnothing$, and $7 \mathrm{e} / 8 \mathrm{~N}$. Of these, only $7 \mathrm{e} / 8 \mathrm{i}$ is mostly conservative. The innovative $7 \varnothing / 8 \varnothing$ subclass is the biggest in terms of noun membership and the catalyzer of paradigm levelling: nouns with an erstwhile prefix reanalyzed as part of the root take a zero/zero noun class prefix and display $7 / 8$ agreement. Due to prefixal consonant loss and mergers, historical 9/10 nouns (recognizable by the presence of a frozen homorganic nasal as part of their synchronic root) were reassigned mainly to subclass $7 \varnothing / 8 \varnothing$. This is certainly the case for all nouns denoting animals. Subclass $7 \varnothing / 8 \varnothing$ also contains all other instances of prefix reanalysis as part of the noun root, e.g.: Ø-w̌m 'fear' (< PB CL14 *bù- +BLR 3543 *jómà 'fear'), $\varnothing$-dzùó 'civet cat' $(<$ PB CL5 augment *dì- + BLR 6882 *jòbó 'civet cat'), Ø-lîm 'song' $(<\mathrm{PB}$ CL5 augment *dì-+ BLR 3364 *jímbò 'song'), Ø-vì̀ 'mushroom (gen.)' (<CL6 *mà- +BLR 5638 *jìbù). In some cases, the bare root was integrated as such into the $7 \varnothing / 8 \varnothing$ pairing: $\emptyset$-tiil 'excrement' $(<$ BLR 6040 *tìtr), Ø-lwǒn 'sleep' (< BLR 3001 *tòngò). The innovative 7e/8N subclass contains reflexes of reconstructed nouns belonging to one or more of the following pairings in the Bantu Lexical Reconstructions (BLR) 2/3 database (Bastin et al. 2002): 7/8, 9/10, and 11/10 (e.g. BLR 1621 *jùgú 'groundnut' 9/10, 11/10; BLR 973 *dímì 'tongue' 7/8, 11/10; BLR 1294 *gádà 'nail' 7/8, 9/10; BLR 897 *dèdù 'beard, chin' 7/8, 9/10, 11/10; BLR 900 *dègè 'weaver bird' 9/10). The singular è- prefix of $7 \mathrm{e} / 8 \mathrm{~N}$ represents the merger of former CL 7 and CL 9 nouns. Possibly, $\grave{e}$ - instead of zero as the singular prefix for this class might have been favored by analogy with class $11 / 8 \mathrm{~N}$ (see discussion below). As for the

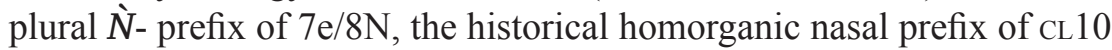
of many nouns reassigned in this subclass was preserved, while its agreement shifted to CL8. Conceivably, this plural prefix was then extended to nouns which historically made their plural in PB CL8 *bì-.

Other innovative class pairings in Ngwi are $11 / 8 \mathrm{~N}, 7 \varnothing / 2$, and $7 / 6$. Only a couple of $11 / 8 \mathrm{~N}$ Ngwi nouns (see (90)) can be linked to protoforms reconstructed in BLR3, namely ò-š̌b / n-tsว̌b < BLR 631 "còbó 'intestines' and ò-kwònj̀ / $\eta$-kwòỳ̀ < BLR 1450 *gòngò 'back, 
backbone'. Both of these are reconstructed in 3/4. Existing BLR3 reconstructions with meanings similar to those of other $11 / 8 \mathrm{~N}$ Ngwi nouns (e.g. 'creeper', 'twig') are reconstructed in singular classes 3, 9, 11. Plural classes are not indicated. As discussed above, due to consonant loss, the singular $\grave{o}$ - noun class prefix in $11 / 8 \mathrm{~N}$ nouns could be either a reflex of PB CL3 *mù- or of PB CL11 *dù-. In the same vein, the $\grave{o}$ agreement prefix triggered on NP constituents and the verb could be a reflex of either PB CL3 pronominal prefix * $g u ́-$ or PB CL11 prononimal prefix *dú-. We posit 11 as a distinct synchronic class for two reasons: (i) it makes its plural only in CL8N (while CL3 makes its plural only in CL4); and (ii) the subject indexes of CL3 and CL11 are distinct, $\grave{o}$ - and $\grave{e}$ - respectively. The fact that, as discussed above, $8 \mathrm{~N}$ was in all likelihood CL10 historically would lead one to think that $11 / 8 \mathrm{~N}$ nouns were originally 11/10, a noun class pairing which in many other Bantu languages contains long, thin objects, languages, body parts, natural phenomena, and utensils, among others (Maho 1999; Katamba 2003). The synchronic semantic content of $11 / 8 \mathrm{~N}$ in (90) offers some evidence in favor of this claim (intestines and backbone are body parts, creepers, whips, and twigs are elongated objects). Possibly, this class once contained many more nouns which might have shifted to class pairing $7 / 8 \mathrm{~N}$ by analogy, because these two pairings share the same plural formation. This shift might have been favored by the high frequency of CL7 $\grave{e}$ - as a singular form compared to CL11 $\grave{o}-$.

CL7Ø/2 is likely to be related to PB class pairing $1 \mathrm{a} / 2$. This class pairing lacked a singular noun class prefix in $\mathrm{PB}$, usually contained kinship terms and triggered CL1 human agreement (Van de Velde 2019: 240-241). Several PB CL1a/2 nouns such as BLR 2806 "tààtá 'father'

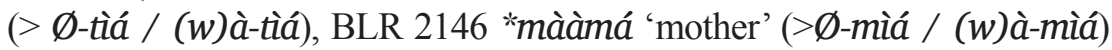
occur in class pairing 7Ø/2 in Ngwi. Other kinship terms historically belonging to CL1/2 such as BLR 1183 *dúmè 'husband' (> Ø-wûm / à-wûm) and BLR 3203 *jánà 'child' (> Ø-môn / à-mân) $)^{21}$ were

${ }^{21}$ The root-initial $/ \mathrm{m} /$ in $\emptyset$-môn / à-mân is likely the result of the reanalysis of an erstwhile prefix of CL1 (PB *mù-) as part of the simple noun stem. 
reassigned to $7 \varnothing / 2$. Across Bantu languages, the plurals of inherited PB CL1a/2 nouns are marked by a $b a(a)$ - or (b)o- prefix. Possibly, the optional plural noun class prefix $w a$ - which a few $7 \varnothing / 2$ nouns display (see (70)) might be the reflex of a historical bàà- plural prefix. Whatever the case might be, while all human-denoting 1/2 nouns in Ngwi (including human-denoting historical $9 / 10$ nouns reassigned to this pairing) trigger human agreement across the board (see §3.1.1), those in $7 \varnothing / 2$ trigger CL7 $\grave{e}$ - NP agreement in the singular despite the fact that they denote humans. When the few CL7Ø/2 nouns in (70), most of which are kinship terms, optionally make their plural in wà-, they trigger CL8 $i$ - non-human NP agreement also in the plural. This seems to suggest that the CL7Ø/2 nouns in (70) reflect an older stage of the language, one where these nouns triggered CL7/8 non-human NP agreement both in the singular and the plural. This non-human NP agreement for nouns denoting humans is striking because it is rare from a Bantu perspective.

Class pairing 7/6 contains only two nouns, è-pfún / à-pfún 'testicle' and $\emptyset$-vâm / à-vâm 'thing'. It is thus hard to outline its evolution. In BLR3, reconstructed nouns meaning 'thing' are assigned to class pairing $7 / 8$, while most of those meaning 'testicle' are assigned to class pairing 5/6. Pairing 7/6 is also attested in WCB varieties such as Bwala (Bollaert et al. 2021) and seems to have a relatively wide distribution in Bantu more generally (Maho 1999: 166-167).

One last question to be addressed in this section is whether any of the innovations observed in Ngwi are also observed in other WCB languages and if so, whether they could be diagnostic for internal classification. Because these innovations are morphological, they undoubtedly weigh more than shared vocabulary and even more than shared phonological innovations. Most diachronically informed analyses of noun class systems in WCB (Niama-Niama 2016; Bollaert 2019; Hyman et al. 2019; Bollaert et al. 2021) target language varieties belonging to the lowest nodes of the WCB phylogeny and are thus far removed from Ngwi, one of the first paraphyletic varieties to split off from the ancestral WCB node. A particularly useful source in this respect 
is Bollaert (2019), a comparative study of noun class systems of ten WCB varieties belonging to Guthrie's B50-80 groups. In the phylogeny of Pacchiarotti et al. (2019), B50-80 languages all belong to the relatively low Kasai-Ngounie Extended node of WCB. Bollaert (2019) lists two innovations which might have happened at Proto-Kasai-Ngounie Extended. These are the merger of PB CL5 $i^{-}$and CL11 *dù- into CL5 * $l i$ - and the presence of two allomorphic noun class prefixes for CL 5 (one as the reflex of PB CL 5 *i- and the other as the reflex of the reconstructed augment of CL $5 * d i-$ ). Innovations which took place only in some of the languages in her sample are: the reassignment of CL15/4 nouns to other noun classes; consonant loss in the inherited PB noun class prefixes; loss of PB 14/6 pairing; a semantic split of the ancient 9/10 nouns whereby some were reclassified as $1 \mathrm{a} / 2$ (or $1 \mathrm{n} / 2$ ) nouns on the grounds of animacy (see also Hyman et al. 2019), while others shifted their plural formation to CL6; and recurrent innovative class pairings such as $5 / 2,5 / 4,5 / 8$, and $14 / 2$. Given that the two (allomorphic) noun class prefixes for CL 5 are also found in Ngwi (see §3.1.3), this innovation is potentially a good candidate to prove the unity of WCB based on shared morphology. As for the rest, prefixal consonant loss also occurred in Ngwi. However, if one grants some sort of validity to the WCB phylogenetic tree in Pacchiarotti et al. (2019), given the phylogenetic positioning of Ngwi (at the very top of the tree), that of B50-80 languages sampled by Bollaert (2019) (in lower nodes), and the fact that many WCB varieties in between have prefixal consonants, the only sensible conclusion is to posit prefixal consonant loss as a parallel independent innovation. As for the reassignment of historical $9 / 10$ nouns to CL1(a)/2 based on animacy, this change happened only very sporadically in Ngwi (see e.g. CL1/2

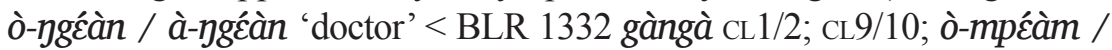
à-mpéàm 'man'< BLR 8211 "pámì cL9/10). As discussed in this section, rather the opposite phenomenon happened in Ngwi: historical 9/10 animal-denoting nouns "remained" in 7/8 (recall that PB CL7 and CL9 merged into CL7, while PB CL8 and CL10 merged into CL8), while many human-denoting nouns were reassigned to $7 \varnothing / 2$ and developed nonhuman NP agreement. 


\section{Conclusions}

In this paper we argued that Ngwi (B861, DRC) has nine synchronic noun classes which can combine into nine noun class pairings. Diachronically, sound change (lowering of PB ${ }^{*} \mathrm{I}$ to /e/ and ${ }^{*} U$ to /o/ and consonant loss) and analogical levelling are responsible for the restructuring of the synchronic Ngwi noun class system. Most class pairings retained from $\mathrm{PB}$ absorbed a considerable amount of nouns which were reassigned to other class pairings due to paradigm levelling. Among the innovative class pairings, subclass $7 \varnothing / 8 \varnothing$ contains the most nouns (including borrowings). Because nouns in this subclass take a zero prefix in the singular and in the plural, if this subclass were to attract more and more nouns and other classes were to level their noun class prefixes by analogy with this major class, one would end up with loss of commutable noun class prefixes and eventually loss of the noun class system itself (see e.g. Crane et al. 2011 on the eroded system of the closely related Nzadi B865). None of the innovative noun class pairings found in Ngwi are shared by phylogenetically and geographically more distant WCB varieties. The account of the Ngwi noun class system offered in this paper suggests that the merger of PB CL11 *dì- and CL5 *ì- into CL5 lì- present in B50-80 WCB varieties is a shared innovation reconstructable to some lower WCB node but not all the way back to Proto-WCB because it is absent in Ngwi, one of the earliest offshoots of the ancestral WCB node. Another potentially relevant conclusion for the genealogical unity of WCB is the presence of two phonologically conditioned noun class prefixes for class 5 , one originating in PB CL5 *i- and the other in the PB augment for CL5 *dì-. This morphological innovation could perhaps be reconstructed to Proto-WCB, because it is goes back to Proto-Kasai-Ngounie (Bollaert 2019), one of the major lower node subgroups of WCB, and is also present in Ngwi, one of the first WCB offshoots. Currently, we do not know whether this morphological innovation could distinguish WCB from other (western) Bantu branches. 


\section{Abbreviations}

Note: In the list below " $\mathrm{x}$ " always stands for a number.

1 (followed by SG or PL) - first person PRF - perfect (anterior)

CLX - noun class prefix of class X PROG - progressive

CONN - connective PRS - present

GEN - general

$\mathrm{s}-$ subject

INT - intensive

$\mathrm{SG}$ - singular

$\mathrm{LF}-$ long form

TR - transitive verb root

o- object

PL - plural

$\mathrm{x}$ - agreement prefix of class $\mathrm{x}$ on NP constituents

\section{Acknowledgments}

This research was funded by the ERC Consolidator Grant \# 724275 granted to the second author and by the FWO (Fonds Wetenschappelijk Onderzoek Vlaanderen) postdoctoral fellowship n ${ }^{\circ} 12 \mathrm{ZV} 721 \mathrm{~N}$ granted to the first author. We are grateful to Sebastian Dom and two anonymous reviewers for their comments.

\section{References}

Ayakum, Jean-Jacques Elala Moke. 2008. Esquisse semantique des emprunts français-ngwi. Bandundu: Institut Superieur Pedagogique de Bandundu extension/section de Mangay. (Travail de fin d'études.)

Bastin, Yvonne \& Coupez, André \& Mumba, Evariste \& Schadeberg, Thilo C. (eds.). 2002. Bantu lexical reconstructions 3. Tervuren: Royal Museum for Central Africa. Online database: linguistics.africamuseum. be/BLR3.html (last accessed November 28, 2017).

Bollaert, Flore. 2019. A historical-comparative study of the noun class systems in the Kasai-Ngounie (extended) languages (Bantu B50-70, B81-84). Ghent: Ghent University. (M.A. thesis.)

Bollaert, Flore \& Pacchiarotti, Sara \& Bostoen, Koen. 2021. The noun class system of Bwala, an undocumented Teke (Bantu, B70z) language from the DRC. Nordic Journal of African Studies 30(1). 1-40. 
Boone, Olga. 1973. Carte ethnique de la République du Zaïre. Quart sudouest. Tervuren: Musée royal de l'Afrique centrale.

Corbett, Greville G. 1991. Gender. Cambridge: Cambridge University Press.

Coupez, André. 1954. Les phonèmes bantous g et $\mathrm{j}$ non précédés de nasale. Zaïre-Afrique 8. 157-161.

Crane, Thera Marie \& Hyman, Larry M. \& Nsielanga Tukumu, Simon. 2011. A grammar of Nzadi (B.865), a Bantu language of the Democratic Republic of Congo with an appendix of Proto-Bantu - Nzadi Sound Correspondences by Clara Cohen. Berkeley: University of California Publications.

De Blois, K.F. 1970. The Augment in the Bantu languages. Africana Linguistica 4. 85-165.

de Rop, Albert Jozef. 1958. Éléments de phonétique historique de lomongo. Léopoldville: Université Lovanium.

di Garbo, Francesca \& Verkerke, Annemarie. 2019. Grammatical restructuring and population dynamics in Northwestern Bantu. Paper presented at the international conference "Africa, the cradle of human diversity", Uppsala Universitet.

Ebalantshim Masuwan, Ngaalandong. 1980. Esquisse grammaticale de la langue idin à Káantsa. Lubumbashi: Université Nationale du Zaïre. (M.A. thesis.)

Empenge Itobola, Frédéric 2008. Etude morpho-semantique des hydronymes ngwi. Bandundu: Institut Superieur Pedagogique de Bandundu. (Travail de fin d'études.)

Garrett, Andrew. 2014. Sound change. In Bowern, Claire \& Evans, Bethwyn (eds.), The Routledge handbook of historical linguistics, 227-248. London: Routledge.

Gene, Niendéka \& Djedje, Madidi. 1986. La culture du riz chez les Ngwi orientaux dans le Nord du Kwilu (Zaïre) : une culture bloquée. Cahiers de la Recherche Développement 11. 42-47.

Grégoire, Claire. 2003. The Bantu languages of the Forest. In Nurse, Derek \& Philippson, Gérard (eds.), The Bantu languages, 349-370. LondonNew York: Routledge.

Güldemann, Tom \& Fiedler, Ines. 2019. Niger-Congo "noun classes" conflate gender with declension. In di Garbo, Francesca \& Wälchli, Bernhard 
(eds.), Grammatical gender and linguistic complexity, 85-135. Berlin: Language Science Press.

Guthrie, Malcolm. 1953. The Bantu languages of Western Equatorial Africa. London - New York: Oxford University Press for the International African Institute.

Guthrie, Malcolm. 1971. Comparative Bantu: An introduction to the comparative linguistics and prehistory of the Bantu languages. Vol. 2. Bantu prehistory, inventory and indexes. London: Gregg International.

Honeybone, Patrick \& Salmons, Joseph (eds.). 2014. The Oxford handbook of historical phonology. Oxford: Oxford University Press.

Hyman, Larry M. 1998. Positional prominence and the 'prosodic trough' in Yaka. Phonology 15(1). 41-75.

Hyman, Larry M. 2008. Directional asymmetries in the morphology and phonology of words, with special reference to Bantu. Linguistics 46(2). 309-350.

Hyman, Larry M. 2014. Reconstructing the Niger-Congo verb extension paradigm: What's cognate, copied or renewed? In Robbeets, Martine \& Bisang, Walter (eds.), Paradigm change in the Transeurasian languages and beyond, 103-125. Amsterdam: John Benjamins.

Hyman, Larry. 2019. Segmental phonology. In Van de Velde, Mark \& Bostoen, Koen \& Nurse, Derek \& Philippson, Gérard (eds.), The Bantu languages. $2^{\text {nd }}$ edn., 128-149. Oxford: Routledge.

Hyman, Larry M. \& Lionnet, Florian \& Ngolele, Christophère. 2019. Number and animacy in the Teke noun class system. In Lotven, Samson \& Bongiovanni, Silvina \& Weirich, Phillip \& Botne, Robert \& Obeng, Samuel Gyasi (eds.), African linguistics across the disciplines: Selected papers from the 48th Annual conference on African Linguistics, 89-102. Berlin: Language Science Press.

Kadima, Marcel. 1969. Le système des classes en bantou. Leuven: Vander.

Kamba-Muzenga, Jean-Georges. 2003. Substitutifs et possessifs en bantou. Paris: Peeters.

Kamba Muzenga, Jean-Georges. 1988. Comportement du préfixe nominal de classe 5 en bantou. Annales Aequatoria 9. 89-131. 
Katamba, Francis. 2003. Bantu nominal morphology. In Nurse, Derek \& Philippson, Gérard (eds.), The Bantu languages, 103-120. LondonNew York.

Khang Levy, Nyi-m'shum. 1979. Eléments de grammaire morphologique de la langue lwel. Lubumbashi: Université Nationale du Zä̈re. (Mémoire de licence.)

Kießling, Roland. 2013. On the origin of Niger-Congo nominal classification. In Kikusawa, Ritsuko \& Reid, Lawrence A. (eds.), Historical linguistics 2011: Selected papers from the 20 th International conference on historical linguistics, Osaka, 25-30 July 2011, 43-65. Amsterdam - Philadelphia: John Benjamins.

Koni Muluwa, Joseph \& Bostoen, Koen. 2019. Nsong (B85d). In Van de Velde, Mark \& Bostoen, Koen \& Nurse, Derek \& Philippson, Gérard (eds.), The Bantu languages. $2^{\text {nd }}$ edn., 414-448. Oxford: Routledge.

Kumpel Wossey, Angélique 2001. Morphologie nominale du ngwi Engye. Kinshasa: Institut Superieur Pédagogique de la Gombe. (Mémoire de licence.)

Maalu-Bungi, Crispin, \& Mutombo, H. M. \& Mbula, P. A. \& Motingea Mangulu, André \& Makokila, André \& Mundeke, Léon \& Donzo Bunza, Jean-Pierre \& Nsenga, I.M. 2011. Atlas linguistique de la République Démocratique du Congo (Version révisée 2010). Yaoundé: Editions du CERDOTOLA.

Maddieson, Ian \& Sands, Bonny. 2019. The sounds of the Bantu languages. In Van de Velde, Mark \& Bostoen, Koen \& Nurse, Derek \& Philippson, Gérard (eds.), The Bantu languages. $2^{\text {nd }}$ edn., 79-127. Oxford: Routledge. Maho, Jouni F. 1999. A comparative study of Bantu noun classes. Göteborg: Acta Universitatis Gothoburgensis.

Maho, Jouni Filip. 2009. NUGL Online: The online version of the new updated Guthrie list, a referential classification of the Bantu languages (June 4, 2009). http://goto.glocalnet.net/mahopapers/nuglonline.pdf

Marlo, Michael R. \& Odden, David. 2019. Tone. In Van de Velde, Mark \& Bostoen, Koen \& Nurse, Derek \& Philippson, Gérard (eds.), The Bantu languages. $2^{\text {nd }}$ edn., $150-171$. London: Routlegde.

Meeussen, Achiel Emiel. 1967. Bantu grammatical reconstructions. Africana Linguistica 3. 79-121. 
Meeussen, Achiel Emiel. 1969. Bantu lexical reconstructions. Tervuren. Ms. Mulumba, Joachim Munampala. 2008. Morphologie flexionelle de ngwi du secteur Bulwem parler d'oyu. Bandundu: Institut Superieur Pédagogique de Bandundu extension/section de Mangai. (Travail de fin d'études.)

Niama-Niama, Japhet. 2016. La diachronie du yilumbu (B 44), parlé à Mayumba: Éléments de phonologie et de morphologie nominale. Libreville: Université Omar Bongo. (M.A. thesis.)

Nsumuki, Wankani. 1993. Formation des substantifs par composition en ngwi. Kinshasa: Institut Pedagogique National. (Travail de fin d'etudes.)

Odden, David \& Bickmore, Lee. 2014. Melodic tone in Bantu. Africana Linguistica 20. 3-13.

Odden, David. 2015. Bantu phonology. In Oxford handbooks online. Oxford: Oxford University Press. http://www.oxfordhandbooks.com/view/10.1093/ oxfordhb/9780199935345.001.0001/oxfordhb-9780199935345-e-59.

Ohala, John J. \& Solé, Maria-Josep. 2008. Turbulence \& phonology. UC Berkeley PhonLab Annual Report 4(4). 297-355.

Pacchiarotti, Sara. In prep. Melodic tone in Ngwi.

Pacchiarotti, Sara \& Bostoen, Koen. 2020. The Proto-West-Coastal Bantu velar merger. Africana Linguistica 26. 139-195.

Pacchiarotti, Sara \& Bostoen, Koen. Forthcoming. Erratic velars in WestCoastal Bantu: Explaining irregular sound change in Central Africa. Journal of Historical Linguistics 12.

Pacchiarotti, Sara \& Bostoen, Koen. In prep. A phonological sketch of Ngwi. Pacchiarotti, Sara \& Chousou-Polydouri, Natalia \& Bostoen, Koen. 2019. Untangling the West-Coastal Bantu mess: Identification, geography and phylogeny of the Bantu B50-80 languages. Africana Linguistica 25. $155-229$.

Pacchiarotti, Sara \& Maselli, Lorenzo \& Bostoen, Koen. Under review. The emergence of interior vowels and heterosyllabic vowel sequences in Ngwi. Papers in Historical Phonology.

Van de Velde, Mark. 2013. The Bantu connective construction. In Carlier, Anne \& Verstraete, Jean-Christophe (eds.), The genitive, 217-252. Amsterdam: John Benjamins. 
Van de Velde, Mark. 2019. Nominal morphology and syntax. In Van de Velde, Mark \& Bostoen, Koen \& Nurse, Derek \& Philippson, Gérard (eds.), The Bantu languages. $2^{\text {nd }}$ edn., 237-269. London: Routledge.

Wills, Jeffrey. Forthcoming. Sorting out Proto-Bantu *j. In Bostoen, Koen \& de Schryver, Gilles-Maurice \& Guérois, Rozenn \& Pacchiarotti, Sara (eds.), Reconstructing Proto-Bantu grammar. Berlin: Language Science Press.

Received 09.02.2021. Received in revised form 21.07.2021. Accepted 21.07.2021 